Published in final edited form as:

Biochemistry. 2016 May 10; 55(18): 2661-2670. doi:10.1021/acs.biochem.5b01350.

\title{
Effect of Different Divalent Cations on the Kinetics and Fidelity of RB69 DNA Polymerase
}

\author{
Ashwani Kumar Vashishtha and William H. Konigsberg* \\ Department of Molecular Biophysics and Biochemistry, Yale University, New Haven, Connecticut \\ 06520-8024, United States
}

\section{Abstract}

Although $\mathrm{Mg}^{2+}$ is the cation that functions as the cofactor for the nucleotidyl transfer reaction for almost all DNA polymerases, $\mathrm{Mn}^{2+}$ can also serve, but when it does, the degree of base discrimination exhibited by most DNA polymerases (pols) is diminished. Metal ions other than $\mathrm{Mg}^{2+}$ or $\mathrm{Mn}^{2+}$ can also act as cofactors depending on the specific DNA polymerase. Here, we tested the ability of several divalent metal ions to substitute for $\mathrm{Mg}^{2+}$ or $\mathrm{Mn}^{2+}$ with RB69 DNA polymerase (RB69pol), a model B-family pol. Our choice of metal ions was based on previous studies with other DNA pols. $\mathrm{Co}^{2+}$, and to a lesser extent $\mathrm{Ni}^{2+}$, were the only cations among those tested besides $\mathrm{Mg}^{2+}$ and $\mathrm{Mn}^{2+}$ that could serve as cofactors with RB69pol. The incorporation efficiency of correct dNMPs increased by 5 -fold with $\mathrm{Co}^{2+}$, relative to that of $\mathrm{Mg}^{2+}$. The incorporation efficiencies of incorrect dNMPs increased by 2-17-fold with $\mathrm{Co}^{2+}$, relative to that with $\mathrm{Mg}^{2+}$ depending on the incoming dNTP. Base selectivity was reduced even further with $\mathrm{Mn}^{2+}$ compared to that observed with $\mathrm{Co}^{2+}$. Substitution of $\mathrm{Mn}^{2+}, \mathrm{Co}^{2+}$, or $\mathrm{Ni}^{2+}$ for $\mathrm{Mg}^{2+}$ reduced the exonuclease activity of RB69pol by 2-, 6-, and 33-fold, respectively, contributing to the frequency of misincorporation. In addition, $\mathrm{Co}^{2+}$ and $\mathrm{Mn}^{2+}$ were better able to extend a primer past a mismatch than $\mathrm{Mg}^{2+}$. Finally, $\mathrm{Co}^{2+}$ and $\mathrm{Mn}^{2+}$ enhanced ground-state binding of both correct and incorrect dNTPs to RB69pol:dideoxy-terminated primer-template complexes.

\section{Graphical Abstract}

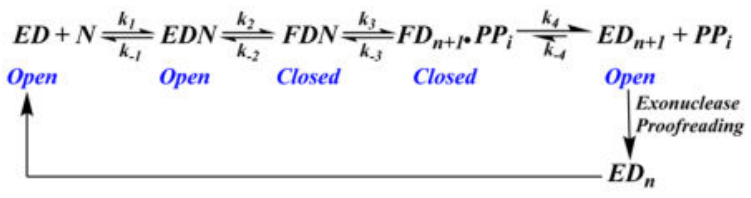

\footnotetext{
*Corresponding Author: Department of Biophysics and Biochemistry, Yale University, 333 Cedar St., SHM CE-14, New Haven, CT 06520-8024. william.konigsberg@yale.edu. Telephone: (203) 785-4599. Fax: (203) 785-7979.

Notes

The authors declare no competing financial interest.

Supporting Information

The Supporting Information is available free of charge on the ACS Publications website at DOI: 10.1021/acs.biochem.5b01350. Additional data showing the optimal divalent cation concentrations (Figure S1), equilibrium fluorescence titration results with increasing dTTP concentrations (or dCTP concentrations) (Figure S2), plots for incorporation of dATP opposite dT past DNA containing $\mathrm{dA} / \mathrm{dC}$ mismatch (Figure S3), plots for incorporation of dATP opposite dT past DNA containing dA/dG mismatch (Figure $\mathrm{S} 4$ ), exonuclease activity of RB69pol using $\mathrm{Ni}^{2+}$ (Figure S5), and calculation of $K_{\mathrm{d}, \mathrm{ca}}$ in competition with $\mathrm{Mg}^{2+}$ (Figure S6) (PDF)
} 
DNA polymerases play a vital role in replicating genomic DNA with remarkably high fidelity. ${ }^{1}$ All DNA polymerases need $\mathrm{Mg}^{2+}$ or $\mathrm{Mn}^{2+}$ to catalyze both nucleotidyl transfer and intrinsic $3^{\prime} \rightarrow 5^{\prime}$ exonuclease activities. Although DNA polymerases employ the physiologically relevant $\mathrm{Mg}^{2+}$, they can use other divalent metal ions such as $\mathrm{Mn}^{2+}$ even though $\mathrm{Mn}^{2+}$ reduces base selectivity. ${ }^{2-5}$ Two metal ions have been shown to be required for primer extension; one metal ion occupying the " $\mathrm{A}$ " site helps to lower the $\mathrm{p} K_{\mathrm{a}}$ of the terminal $3^{\prime}-\mathrm{OH}$ group on the primer and coordinates both the $a$-phosphate of incoming $\mathrm{dNTP}$ and the $3^{\prime}-\mathrm{OH}$ of the primer strand, which facilitates its nucleophilic attack on the dNTP's $a$-phosphorus atom. ${ }^{6}$ The other metal ion occupying the "B" site coordinates the $a$-, $\beta$ - and $\gamma$-phosphate oxygens of the incoming dNTP and helps to neutralize the developing negative charge of the transition state in the nucleotidyl transfer reaction, assisting the departure of $\mathrm{PP}_{\mathrm{i}}$. The effect of metal ions on the fidelity of DNA replication has been studied for several pols. ${ }^{2,7-12}$ Some metal ions have been shown to be mutagens and carcinogens possibly due in part to the fact that DNA replication fidelity is reduced. ${ }^{2,7-11,13}$

Pelletier et al. ${ }^{3}$ have conducted extensive structural studies of pol $\beta$ ternary complexes with many different metal ions and showed that only $\mathrm{Mg}^{2+}, \mathrm{Mn}^{2+}, \mathrm{Cd}^{2+}$, and $\mathrm{Zn}^{2+}$ catalyzed dNMP incorporation. Egli et al. ${ }^{5}$ reported that $\mathrm{Mg}^{2+}, \mathrm{Mn}^{2+}$, and $\mathrm{Ca}^{2+}$ are active for Dpo4catalyzed polymerization but $\mathrm{Co}^{2+}, \mathrm{Ni}^{2+}, \mathrm{Cu}^{2+}, \mathrm{Zn}^{2+}, \mathrm{Ba}^{2+}$, and $\mathrm{Sr}^{2+}$ are not. $\mathrm{Pol} \beta$ and Dpo4 are X- and Y-family pols and have different preferences for metal ion cofactors; however, there have not been extensive studies of the effect of divalent cations on the kinetics and fidelity of B-family pols. Thus, we decided to determine the metal ion preference for RB69pol, a high-fidelity model B-family DNA polymerase. ${ }^{14,15}$

Here we report how different divalent cations influence base selectivity by determining the pre-steady-state kinetic parameters for primer extension with incoming dNTPs that are either complementary or unmatched with the templating base. We have also determined the effect of various divalent cations on the ground-state binding affinity of dTTP and dCTP against a templating dAP by recording their ability to quench $2 \mathrm{AP}$ fluorescence as a function of dNTP concentration. We have also looked at the influence of different divalent metal ions on their ability to allow RB69pol to extend primers bearing mismatched bases at their $3^{\prime}$-termini. In addition, we have investigated how these active divalent cations affect the exonuclease activity of RB69pol. Finally, we speculate about why $\mathrm{Mg}^{2+}, \mathrm{Mn}^{2+}, \mathrm{Co}^{2+}$, and to a much lesser extent $\mathrm{Ni}^{2+}$ are the only metal ions among those tested that can activate the pol and exo activities of $\mathrm{RB} 69 \mathrm{pol}$ and why $\mathrm{Co}^{2+}$ and $\mathrm{Mn}^{2+}$ reduce base selectivity.

\section{MATERIALS AND METHODS}

\section{Chemicals}

All chemicals were of the highest grade available and were used as purchased. dNTPs were from Roche (Burgess Hill, U.K.). T4 polynucleotide kinase was from New England Biolabs (Ipswich, MA), and $\left[\gamma_{-}{ }^{32} \mathrm{P}\right]$ ATP was from MP Biomedicals (Irvine, CA). The metal ion salts $\left[\mathrm{MgCl}_{2}, \mathrm{MnCl}_{2}, \mathrm{CaCl}_{2}, \mathrm{Zn}\left(\mathrm{CH}_{3} \mathrm{COO}\right)_{2}, \mathrm{CoCl}_{2}, \mathrm{CdSO}_{4}, \mathrm{CuSO}_{4}, \mathrm{NiCl}_{2}, \mathrm{SrCl}_{2}, \mathrm{BeCl}_{2}\right.$, $\mathrm{BaCl}_{2}$, and $\left.\mathrm{CrKSO}_{4}\right]$ were from Fluka and were reported to be $>99 \%$ pure. 


\section{DNA Substrates}

Oligonucleotides were synthesized at the Keck Facility (Yale University), and primers labeled with fluorescein at the $5^{\prime}$-end were obtained from Integrated DNA Technologies (Coralville, IA). Oligonucleotides were gel purified using polyacrylamide gel electrophoresis (PAGE) [19:1 (w/v) acrylamide/bis(acrylamide) gels containing $8 \mathrm{M}$ urea]. A fluorescein-labeled primer was annealed to unlabeled templates when they were heated to $95{ }^{\circ} \mathrm{C}$ and then slowly cooled to $25^{\circ} \mathrm{C} .{ }^{16}$ For studies using $2 \mathrm{AP}$ as the templating base, the primer was labeled with $\left[\gamma^{-32} \mathrm{P}\right]$ ATP using T4 polynucleotide kinase. The P/T sequences used in all assays are shown in Figure 1. To simplify the interpretation of data, a common primer sequence was annealed to different templates where the templating base was varied.

\section{Enzymes}

Wild-type $\mathrm{exo}^{+}$and exo- RB69pols were overexpressed in Escherichia coli, purified, and stored as previously described. ${ }^{17} \mathrm{Pol} \beta$ was a generous gift from S. Wilson (National Institute of Environmental Health Sciences, National Institutes of Health, Research Triangle Park, NC). An RW382 culture of an E. coli strain harboring the Dpo4 expression plasmid was provided by W. Yang (National Institutes of Health, Bethesda, MD). Protein expression was conducted as described previously. ${ }^{18}$ Cells were harvested and lysed using a microfluidizer followed by heat denaturation at $75{ }^{\circ} \mathrm{C}$ to remove the thermolabile $E$. coli proteins followed by ultracentrifugation at $45000 \mathrm{rpm}$ for $1 \mathrm{~h}$ to remove the cell debris. The supernatant was dialyzed overnight against heparin A buffer that contained $150 \mathrm{mM} \mathrm{NaCl}$, $50 \mathrm{mM}$ Tris (pH 7.4), and $1 \mathrm{mM}$ EDTA (pH 8.0), loaded onto a heparin column, and washed with buffer A. Dpo4 was eluted using heparin buffer B containing $800 \mathrm{mM} \mathrm{NaCl}, 50 \mathrm{mM}$ Tris (pH 7.4), and $1 \mathrm{mM}$ EDTA (pH 8.0). Fractions were analyzed via sodium dodecyl sulfate (SDS)-PAGE, and those containing Dpo4 as shown by SDS-PAGE were pooled and dialyzed overnight against protein storage buffer containing $20 \mathrm{mM}$ Tris- $\mathrm{HCl}(\mathrm{pH} \mathrm{7.3)}, 100$ $\mu \mathrm{M}$ EDTA, and $5 \%(\mathrm{w} / \mathrm{v})$ glycerol. The dialyzed protein was concentrated to $6 \mathrm{mg} / \mathrm{mL}$, flash-frozen in liquid nitrogen, and stored in small aliquots at $-80{ }^{\circ} \mathrm{C}$.

\section{Steady-State Kinetic Assays for the Metal Ion Dependence of RB69pol}

Steady-state kinetic assays were used to screen selected metal ions for their ability to support the pol and exo activities of RB69pol. A typical assay mixture contained $66 \mathrm{mM}$ Tris- $\mathrm{HCl}$ (pH 7.3), $200 \mathrm{nM}$ 13/18-mer, $40 \mathrm{nM} \mathrm{RB69pol} \mathrm{exo-} \mathrm{enzyme,} \mathrm{and} 10 \mathrm{mM} \mathrm{CoCl}_{2}$. The mixture was preincubated at $23{ }^{\circ} \mathrm{C}$ for $10 \mathrm{~min}$ and the reaction initiated by adding 500 $\mu \mathrm{M}$ dTTP. Aliquots $(10 \mu \mathrm{L})$ were quenched with $0.5 \mathrm{M}$ EDTA at 10, 20, 40, 60, and $120 \mathrm{~s}$. The experiment was repeated using $\mathrm{MnCl}_{2}, \mathrm{CaCl}_{2}, \mathrm{Zn}\left(\mathrm{CH}_{3} \mathrm{COO}\right)_{2}, \mathrm{CdSO}_{4}, \mathrm{CuSO}_{4}, \mathrm{NiCl}_{2}$, $\mathrm{SrCl}_{2}, \mathrm{FeCl}_{2}, \mathrm{BaCl}_{2}$, and $\mathrm{CrKSO}_{4}$. To determine the optimal concentrations of $\mathrm{Co}^{2+}, \mathrm{Mn}^{2+}$, and $\mathrm{Ni}^{2+}$ (which were the only metal ions that worked), rates of primer extension were measured under steady-state conditions using different concentrations of these metal ions ranging from 2 to $20 \mathrm{mM}$.

\section{Nucleotide Incorporation under Single-Turnover Conditions Catalyzed by Exo- RB69pol}

Rapid chemical quench assays were performed at $23{ }^{\circ} \mathrm{C}$ with an $\mathrm{RQF} 3$ rapid chemical quench instrument (Kintek Corp.). Exo- RB69pol (1 $\mu \mathrm{M})$ was incubated with a 13/18-mer 
$\mathrm{P} / \mathrm{T}(80 \mathrm{nM})$ in assay buffer containing EDTA $(0.1 \mathrm{mM})$ and $66 \mathrm{mM}$ Tris- $\mathrm{HCl}(\mathrm{pH} 7.3)$ and mixed with dTTP (10-500 $\mu \mathrm{M})$ containing $\mathrm{MnCl}_{2}, \mathrm{CoCl}_{2}$, or $\mathrm{NiCl}_{2},(10 \mathrm{mM})$ in assay buffer (final concentrations after mixing). The reactions were quenched with $0.5 \mathrm{M}$ EDTA (pH 8.0) at various times ranging from $3 \mathrm{~ms}$ to $1 \mathrm{~s}$. For the incorporation of an incorrect nucleotide, the dNTP concentrations were varied from $50 \mu \mathrm{M}$ to $3 \mathrm{mM}$ and reactions were quenched at times ranging from $500 \mathrm{~ms}$ to $180 \mathrm{~min}$. Products were separated by PAGE [19:1 (w/v) acrylamide/bis-(acrylamide) gels containing $8 \mathrm{M}$ urea], visualized using a FUJI scanner equipped with a $473 \mathrm{~nm}$ fluorescent laser signal, and quantified using MULTIGAUGE (Science Lab 2005) and GraphPad Prism. Assays involving 2AP as the templating base were conducted similarly except that the gels were visualized using a STORM imager (Molecular Imaging) and quantified using ImageQuant (GE Healthcare) and GraphPad Prism.

\section{Exonuclease Assays with Exo+ $\mathrm{RB}^{+} 9 \mathrm{pol}$ Using $\mathrm{Mn}^{2+}, \mathrm{Co}^{2+}$, and $\mathrm{Ni}^{2+}$}

Rapid chemical quench assays were performed as mentioned above to determine the rate of excision $\left(k_{\text {exo }}\right)$ in the presence of $\mathrm{Mn}^{2+}, \mathrm{Co}^{2+}$, and $\mathrm{Ni}^{2+}$. $\mathrm{RB} 69$ pol exo ${ }^{+}(1 \mu \mathrm{M})$ was incubated with 13/18-mer $(80 \mathrm{nM})$ in reaction buffer containing EDTA $(0.1 \mathrm{mM})$ and mixed with $10 \mathrm{mM} \mathrm{Co}^{2+}, \mathrm{Mn}^{2+}$, or $\mathrm{Ni}^{2+}$, in assay buffer. The reactions were quenched with $0.5 \mathrm{M}$ EDTA (pH 8.0) at times ranging from $4 \mathrm{~ms}$ to $5 \mathrm{~s}$. The exonuclease reaction in the presence of $\mathrm{Ni}^{2+}$ was slow; hence, assays were conducted on the benchtop (10 s to $30 \mathrm{~min}$ ).

\section{Pre-Steady-State Kinetic Experiments for Insertion and Extension beyond a Mismatched $\mathbf{P} / \mathbf{T}$}

Single-turnover experiments were conducted as described above except that the P/T terminus contained a dA/dC or dA/dG mismatch as shown in Figure 1. Exo ${ }^{-} \mathrm{RB} 69 \mathrm{pol}$ (1 $\mu \mathrm{M})$ was incubated with $13 / 18$-mer $(80 \mathrm{nM})$ in assay buffer containing EDTA $(0.1 \mathrm{mM})$ and mixed with dATP $(0.05-3 \mathrm{mM})$ containing $\mathrm{Mg}^{2+}(10 \mathrm{mM}), \mathrm{Co}^{2+}(10 \mathrm{mM})$, or $\mathrm{Mn}^{2+}(10$ $\mathrm{mM}$ ), in assay buffer. The reactions were quenched with $0.5 \mathrm{M}$ EDTA (pH 8.0) at various times ranging from $0.5 \mathrm{~s}$ to $20 \mathrm{~min}$. Six different dATP concentrations were employed for each $k_{\text {pol }}$ and $K_{\text {d,app }}$ determination.

\section{Equilibrium Fluorescence Titrations}

The emission spectra of deoxy-primer/templates $(\mathrm{dP} / \mathrm{T})$ or dideoxy-primer/templates $(\mathrm{ddP} / \mathrm{T})$ containing $2 \mathrm{AP}$ were recorded at $23^{\circ} \mathrm{C}$ with a Photon Technology International Alphascan scanning spectrofluorometer. The titration mixture contained $66 \mathrm{mM}$ Tris- $\mathrm{HCl}$ (pH 7.3), $200 \mathrm{nM}$ P/T (13/18-mer; dP/T or ddP/T) with $2 \mathrm{AP}$ as the templating base (Figure 1), $1 \mu \mathrm{M}$ exo- RB69 pol, and either $10 \mathrm{mM} \mathrm{MgCl}_{2}, 10 \mathrm{mM} \mathrm{CoCl}_{2}, 10 \mathrm{mM} \mathrm{MnCl}_{2}$, or $2 \mathrm{mM}$ $\mathrm{CaCl}_{2}$ with varying dTTP and dCTP concentrations. A dP/T was used to conduct the titration in the presence of $2 \mathrm{mM} \mathrm{Ca}^{2+}$ because $\mathrm{Ca}^{2+}$ prevents primer extension and allows the dNTP to bind to the binary complex in the absence of chemistry. ${ }^{19}$ Samples were excited at $313 \mathrm{~nm}$, and fluorescence emission spectra were recorded from 335 to $450 \mathrm{~nm}$ after 2 min to allow the reaction to come to equilibrium where no further change in fluorescence intensity was observed. The intensities for all samples were corrected by subtracting the intensity of the blank sample and protein that contained $66 \mathrm{mM}$ Tris- $\mathrm{HCl}(\mathrm{pH} 7.3)$ and the respective metal ion concentration mentioned above. Peak emission intensities at $365 \mathrm{~nm}$ were plotted as a function of dTTP concentration (or dCTP concentration) and fit to a 
hyperbolic equation to obtain the ground-state equilibrium dissociation constant $\left(K_{\mathrm{dg}}\right)$ for incoming dTTP (or dCTP).

\section{Measurement of $K_{\mathrm{d} \text {,app }}$ for $\mathrm{Ca}^{2+}$ in Competition with $\mathrm{Mg}^{2+}$ for Primer Extension}

Competition experiments were performed as described above. Briefly, a mixture containing exo $^{-}$RB69pol $(1 \mu \mathrm{M})$ and 13/18-mer $(80 \mathrm{nM})$ in assay buffer containing EDTA $(0.1 \mathrm{mM})$ was mixed with dTTP $(1 \mathrm{mM})$ containing $\mathrm{Mg}^{2+}(10 \mathrm{mM})$ and $\mathrm{Ca}^{2+}(50 \mu \mathrm{M})$, in assay buffer. The reactions were quenched with $0.5 \mathrm{M}$ EDTA ( $\mathrm{pH}$ 8.0) at intervals ranging from 4 to 100 ms. The experiment was repeated with varying $\mathrm{Ca}^{2+}$ concentrations (from 0.1 to $20 \mathrm{mM}$ ).

\section{Nucleotide Incorporation Assays for Dpo4 and Pol $\beta$}

Dpo4 $(20 \mathrm{nM})$ was incubated with 13/18-mer $(1 \mu \mathrm{M})$ in reaction buffer containing EDTA $(0.1 \mathrm{mM})$ and mixed with dTTP $(1 \mathrm{mM})$ containing $\mathrm{Co}^{2+}(10 \mathrm{mM})$ in the standard assay buffer in the absence and presence of $2 \mathrm{mM}$ DTT. Reactions were quenched with $0.5 \mathrm{M}$ EDTA (pH 8.0) at intervals ranging from 1 to $15 \mathrm{~min}$. Assays for pol $\beta$ were conducted by incubating pol $\beta(1 \mu \mathrm{M})$ with $13 / 18$-mer $(80 \mathrm{nM})$ in reaction buffer containing EDTA (0.1 $\mathrm{mM})$ and mixed with dTTP $(1 \mathrm{mM})$ containing $\mathrm{Co}^{2+}(10 \mathrm{mM})$ in standard assay buffer. Reactions were quenched with $0.5 \mathrm{M}$ EDTA at intervals ranging from 10 to $80 \mathrm{~s}$.

\section{Data Analysis}

The amount of product formed at each dNTP concentration at different times was fit by nonlinear regression to eq 1 , and the observed rates of product formation at different dNTP concentrations were determined

$$
\text { [product }]=A\left(1-\mathrm{e}^{-k_{\mathrm{obs}}^{t}}\right)
$$

where $A$ is the observed amplitude of product formation and $k_{\mathrm{obs}}$ is the observed rate constant at a particular dNTP concentration. To determine the kinetic parameters $k_{\text {pol }}$ (the maximal rate of nucleotide incorporation) and $K_{\mathrm{d} \text {,app }}$ (the concentration of dNTP at which the rate of nucleotide incorporation is half of $\left.k_{\mathrm{pol}}\right), k_{\mathrm{obs}}$ was plotted against the dNTP concentration, and data were fitted to eq 2 .

$$
k_{\mathrm{obs}}=\frac{k_{\mathrm{pol}}[\mathrm{dNTP}]}{K_{\mathrm{d}, \mathrm{app}}+[\mathrm{dNTP}]}
$$

where $k_{\mathrm{obs}}$ is the observed rate at a given dNTP concentration. In cases in which saturation was not achieved with the incoming dNTP, data were fit to eq 3. 


$$
k_{\mathrm{obs}}=\frac{k_{\mathrm{on}}[\mathrm{dNTP}]}{1+[\mathrm{dNTP}] / K_{\mathrm{d}, \mathrm{app}}}
$$

where $k_{\mathrm{on}}$ is defined as the ratio of $k_{\mathrm{pol}}$ to the $K_{\mathrm{d} \text {,app }}$ value for the incoming dNTP.

Rates of nucleotide excision were determined by plotting the amount of labeled primer from the $\mathrm{P} / \mathrm{T}$ remaining as a function of time, and data were fit to the following equation

$$
Y=\lambda \mathrm{e}^{-k t}+C
$$

where $Y$ is the concentration of the DNA substrate remaining during the reaction, $\lambda$ is the observed amplitude of the substrate remaining, and $k$ is the observed rate constant.

Equilibrium fluorescence titration data were fit to the hyperbolic equation

$$
f=f_{0}+\frac{f_{\text {max }}[\mathrm{dNTP}]}{K_{\mathrm{d}, \mathrm{g}}+[\mathrm{dNTP}]}
$$

where $f$ is the observed fluorescence intensity, $f_{0}$ is the starting fluorescence, $f_{\max }$ is the maximal decrease in fluorescence intensity at a saturating dTTP concentration, and $K_{\mathrm{d}, \mathrm{g}}$ is the ground-state equilibrium dissociation constant for the incoming dNTP. Equilibrium fluorescence data involving tight dNTP binding relative to the enzyme concentration were fit to a quadratic equation.

$$
\Delta F=F_{0}+\frac{F_{\max }\left[D_{\mathrm{o}}+S_{\mathrm{o}}+K_{\mathrm{d}}-\sqrt{\left(D_{0}+S_{0}+K_{\mathrm{d}}\right)^{2}-4 D_{0} S_{0}}\right]}{2 D_{0}}
$$

where $\Delta F$ is the fluorescence signal change, $F_{0}$ is the starting fluorescence, $F_{\max }$ is the maximal fluorescence signal change at saturating dNTP concentrations, $D_{0}$ is the total DNA concentration, $S_{0}$ is the total dNTP concentration, and $K_{\mathrm{d}, \mathrm{g}}$ is the ground-state equilibrium dissociation constant for the incoming dNTP.

Data for competition experiments using $\mathrm{Ca}^{2+}$ were fit to eq 1 to obtain the observed rates for product formation. The $K_{\mathrm{d}}$ for $\mathrm{Ca}^{2+}$ was obtained by fitting the data using eq 7 .

$$
k_{\mathrm{obs}}=\frac{k_{\mathrm{pol}}[\mathrm{Mg}] / K_{\mathrm{d}, \mathrm{Mg}}}{1+[\mathrm{Mg}] / K_{\mathrm{d}, \mathrm{Mg}}+[\mathrm{Ca}] / K_{\mathrm{d}, \mathrm{Ca}}}
$$


where $k_{\mathrm{obs}}$ is the observed rate at a given $\mathrm{Ca}^{2+}$ concentration, $K_{\mathrm{d}, \mathrm{Mg}}$ is the $K_{\mathrm{d}}$ for $\mathrm{Mg}^{2+}$, and $K_{\mathrm{d}, \mathrm{Ca}}$ is the $K_{\mathrm{d}}$ for $\mathrm{Ca}^{2+}$ when it is competing with $\mathrm{Mg}$.

\section{RESULTS}

\section{Effect of Divalent Metal Ions on the Kinetics of Primer Extension Catalyzed by RB69pol}

Steady-state kinetic assays were conducted to determine if metal ions other than $\mathrm{Mg}^{2+}$ and $\mathrm{Mn}^{2+}$ were able to activate RB69 polymerase. We found that only $\mathrm{Co}^{2+}$ and to a lesser extent $\mathrm{Ni}^{2+}$ supported the pol activity of RB69pol. We also tried $\mathrm{Fe}^{2+}, \mathrm{Ca}^{2+}, \mathrm{Zn}^{2+}, \mathrm{Cd}^{2+}, \mathrm{Sr}^{2+}$, $\mathrm{Ba}^{2+}, \mathrm{Cu}^{2+}$, and $\mathrm{Cr}^{3+}$ because these cations were tested with other pols; ${ }^{3,5}$ however, they did not support the pol activity of RB69pol. The rate of dTMP incorporation opposite dA was determined as a function of $\mathrm{Co}^{2+}, \mathrm{Mn}^{2+}$, and $\mathrm{Ni}^{2+}$ concentrations first under steady-state conditions to find the optimal concentration, which was $\sim 10 \mathrm{mM}$ for all three cations (Figure S1). We then used this concentration for pre-steady-state single-turnover experiments to investigate their effect on misincorporation and bypassing a mismatch at the primer terminus.

\section{Single-Turnover Kinetics for Correct Nucleotide Incorporation by Exo- RB69pol}

Although $\mathrm{Mg}^{2+}$ is the physiologically relevant cation that activates RB69pol in vivo, DNA polymerases from human, ${ }^{20}$ viral, ${ }^{21}$ and bacterial ${ }^{8}$ sources can also utilize $\mathrm{Mn}^{2+}, \mathrm{Co}^{2+}$, $\mathrm{Ni}^{2+}$, and $\mathrm{Cd}^{2+}$ in vitro. ${ }^{3} \mathrm{Ca}^{2+}$ has also been shown to activate $\mathrm{Dpo} 4,{ }^{5}$ but this is an exception because $\mathrm{Ca}^{2+}$ is inactive with every other DNA pol that has been tested. The apparent dissociation constant for $\operatorname{dTTP}\left(K_{\mathrm{d}, \mathrm{app}}\right)$ in the presence of $\mathrm{Mg}^{2+}, \mathrm{Mn}^{2+}, \mathrm{Co}^{2+}$, and $\mathrm{Ni}^{2+}$ was determined under single-turnover conditions, where the RB69pol concentration was 12 -fold greater than that of the primer-template (P/T). Under these conditions, $295 \%$ of the DNA is bound to the enzyme. Product concentrations obtained at different dTTP concentrations were plotted against time and fitted to eq 1 to yield $k_{\text {obs }}$ at each dTTP concentration. These rates were plotted against dTTP concentration to extract a $k_{\text {pol }}$ of $>300$ $\mathrm{s}^{-1}$ and a $K_{\mathrm{d} \text {,app }}$ of $56 \mu \mathrm{M}$ with $\mathrm{Mg}^{2+} . k_{\text {pol }}$ values for the incorporation of dTMP opposite dA using $\mathrm{Co}^{2+}$ and $\mathrm{Mn}^{2+}$ were also $>300 \mathrm{~s}^{-1}$. Accurate $k_{\mathrm{pol}}$ values for $\mathrm{Mg}^{2+}, \mathrm{Co}^{2+}$, and $\mathrm{Mn}^{2+}$ could not be determined as the reaction proceeds faster than the $2 \mathrm{~ms}$ dead time of the Kintek instrument. However, the $k_{\text {pol }}$ for incorporation of dTMP opposite dA in the presence of $\mathrm{Ni}^{2+}$ was much lower $\left(0.6 \mathrm{~s}^{-1}\right) . K_{\mathrm{d} \text {,app }}$ values for dTTP incorporation with these metal ions were between 16 and $61 \mu \mathrm{M}$ (Table 1). To directly compare the incorporation efficiencies in the presence of $\mathrm{Mg}^{2+}, \mathrm{Co}^{2+}$, and $\mathrm{Mn}^{2+}$, single-turnover assays were conducted at $6{ }^{\circ} \mathrm{C}$ with $66 \mathrm{mM}$ MES buffer (pH 6.3) to reduce the $k_{\text {obs }}$. The results summarized in Table 2 show that when $\mathrm{Mg}^{2+}$ was replaced with $\mathrm{Co}^{2+}$ or $\mathrm{Mn}^{2+}$, the efficiency of incorporation of dTMP opposite dA increased by 5 - or $\sim 3$-fold, respectively. We note that lowering the $\mathrm{pH}$ from 7.3 to 6.3 may influence the metal binding by altering the protonation states of acidic side chains that coordinate the metal ions.

To investigate the effect of $\mathrm{Mg}^{2+}, \mathrm{Co}^{2+}$, and $\mathrm{Mn}^{2+}$ on ground-state binding affinity $\left(K_{\mathrm{d}, \mathrm{g}}\right)$ and the apparent equilibrium dissociation constant $\left(K_{\mathrm{d} \text {,app }}\right)$ of the incoming dNTPs (Scheme 1 ), we performed single-turnover kinetic assays using P/T containing $2 \mathrm{AP}$ as the templating base (DNA $)$ and measured the $K_{\mathrm{d}, \mathrm{g}}$ values with correct and incorrect incoming nucleotides. 
Pre-steady-state kinetic assays using incorporation of dTMP opposite 2AP showed trends in $k_{\text {pol }}$ and $K_{\mathrm{d} \text {,app }}$ values similar to those for incorporation of dTMP opposite dA at $23{ }^{\circ} \mathrm{C}$. The $k_{\text {pol }}$ values were $>300 \mathrm{~s}^{-1}$ in the presence of $\mathrm{Mg}^{2+}, \mathrm{Co}^{2+}$, and $\mathrm{Mn}^{2+}$, while the $K_{\mathrm{d} \text {,app }}$ values were 167,50 , and $20 \mu \mathrm{M}$, respectively. Similarly, assays were repeated using incorporation of dCMP opposite dAP. Figure 2 shows the plots for incorporation of dCMP opposite dAP in the presence of $10 \mathrm{mM} \mathrm{Mn}^{2+}$ at $23{ }^{\circ} \mathrm{C}$. Assays involving incorporation of dTMP opposite dAP were repeated at $6{ }^{\circ} \mathrm{C}$ using $66 \mathrm{mM}$ MES buffer (pH 6.3) to directly compare the $k_{\text {pol }}$ values obtained with the three metal ions. Among the three cations, the highest incorporation efficiency was obtained in the presence of $\mathrm{Co}^{2+}\left(4 \mu \mathrm{M}^{-1} \mathrm{~s}^{-1}\right)$ followed by $\mathrm{Mn}^{2+}\left(2 \mu \mathrm{M}^{-1} \mathrm{~s}\right.$ $\left.{ }^{-1}\right)$ and $\mathrm{Mg}^{2+}\left(0.6 \mu \mathrm{M}^{-1} \mathrm{~s}^{-1}\right)$. Incorporation efficiencies with DNA containing $2 \mathrm{AP}$ as the templating base $\left(\mathrm{DNA}_{\mathrm{P}}\right.$ ) were in general $\sim 5$-fold lower than that of DNA containing $\mathrm{dA}$ as the templating base with all three metal ions (Table 2).

\section{Single-Turnover Kinetics for Incorporation of the Incorrect Nucleotide by Exo- RB69pol}

To study the effect of $\mathrm{Co}^{2+}, \mathrm{Mn}^{2+}$, and $\mathrm{Ni}^{2+}$ on base selectivity, single-turnover experiments were conducted with incorrect incoming dNTPs. We tested purine:purine, purine:pyrimidine, and pyrimidine:pyrimidine mismatches. In general, $\mathrm{Mg}^{2+}$ and $\mathrm{Co}^{2+}$ showed the greatest base selectivity with all the mispairs (Table 1 ). While the $K_{\text {d,app }}$ values with $\mathrm{Mg}^{2+}, \mathrm{Co}^{2+}$, and $\mathrm{Ni}^{2+}$ were in a similar range, most of the reduction in base selectivity with $\mathrm{Mn}^{2+}$ resulted from a dramatic increase in $k_{\text {pol }}$ values with incorrect incoming dNTPs. Figure 3 shows the plots for incorporation of dAMP opposite $\mathrm{dC}$ in the presence of $10 \mathrm{mM} \mathrm{Co}^{2+}$ at $23{ }^{\circ} \mathrm{C}$. We note that we have compared the $k_{\mathrm{pol}} / K_{\mathrm{d} \text {,app }}$ values for correct nucleotide incorporation obtained at $6{ }^{\circ} \mathrm{C}$ with the $k_{\text {pol }} / K_{\mathrm{d} \text {,app }}$ values for incorrect nucleotide incorporations obtained at $23{ }^{\circ} \mathrm{C}$ because the actual $k_{\text {pol }}$ values at $23{ }^{\circ} \mathrm{C}$ for correct nucleotide incorporations were $>300 \mathrm{~s}^{-1}$ with all three metal ions, so a direct comparison of $k_{\mathrm{pol}} / K_{\mathrm{d} \text {,app }}$ values could not be made.

\section{Effect of Metal lons on Ground-State Binding of dNTP to the Pol-P/T Binary Complex with $\mathrm{Mg}^{2+}, \mathrm{Mn}^{2+}, \mathrm{Co}^{2+}$, and $\mathrm{Ca}^{2+}$}

To examine whether the different metal ions affect the ground-state equilibrium dissociation constant $\left(K_{\mathrm{d}, \mathrm{g}}\right)$ for dTTP binding (opposite $\left.2 \mathrm{AP}\right)$ to a ddP/T-RB69pol binary complex, equilibrium fluorescence titrations were conducted in the presence of $\mathrm{Mg}^{2+}, \mathrm{Co}^{2+}, \mathrm{Mn}^{2+}$, and $\mathrm{Ca}^{2+}$ (Table 3). The $K_{\mathrm{d}, \mathrm{g}}$ for binding of dTTP opposite template 2AP in the presence of $\mathrm{Ca}^{2+}$ using a deoxy-terminated (dP/T) was $170 \mathrm{nM}$, with a $26 \%$ reduction in the amplitude, while the $K_{\mathrm{d}, \mathrm{g}}$ using a ddP/T was $440 \mathrm{nM}$ and resulted in a $75 \%$ reduction in amplitude, indicating that the presence of an $\mathrm{OH}$ group at the $3^{\prime}$-terminus of the primer increased the affinity of dTTP for the binary complex by $\sim 2.5$-fold. Similar decreases in amplitude (72, 72 , and $65 \%$ ) were observed with $\mathrm{Mg}^{2+}, \mathrm{Co}^{2+}$, and $\mathrm{Mn}^{2+}$, respectively. $K_{\mathrm{d}, \mathrm{g}}$ values obtained in the presence of $\mathrm{Mg}^{2+}, \mathrm{Co}^{2+}$, and $\mathrm{Mn}^{2+}$ were 34, 6, and $0.6 \mu \mathrm{M}$, respectively. Figure 4 and Figure S2A show equilibrium fluorescence titration results for the RB69pol-ddP/T complex with increasing dTTP concentrations in the presence of $10 \mathrm{mM} \mathrm{Mg}^{2+}$ and $10 \mathrm{mM} \mathrm{Co}^{2+}$, respectively.

To test whether similar discrimination would be observed for an incorrect incoming dNTP in the presence of these metal ions, we determined the $K_{\mathrm{d}, \mathrm{g}}$ values for dCTP binding opposite 
2AP in the presence of $\mathrm{Mg}^{2+}, \mathrm{Mn}^{2+}$, and $\mathrm{Ca}^{2+}$ by measuring the change in 2AP fluorescence observed as a function of dCTP concentration. The $K_{\mathrm{d}, \mathrm{g}}$ values obtained for dCTP binding in the presence of $\mathrm{Mg}^{2+}, \mathrm{Mn}^{2+}$, and $\mathrm{Ca}^{2+}$ were 1400,34 , and $14 \mu \mathrm{M}$, respectively, demonstrating that $\mathrm{Mn}^{2+}$ and $\mathrm{Ca}^{2+}$ provide 40 - and 100-fold tighter ground-state binding of the incorrect dNTP substrate (dCTP), respectively, compared to that of $\mathrm{Mg}^{2+}$. Figure S2B shows equilibrium fluorescence titration results for the RB69pol-ddP/T complex with increasing dCTP concentrations in the presence of $10 \mathrm{mM} \mathrm{Mn}^{2+}$.

\section{Extension beyond a Mismatched $\mathrm{P} / \mathrm{T}$ with $\mathrm{Mg}^{2+}, \mathrm{Mn}^{2+}$, and $\mathrm{Co}^{2+}$}

We determined how effectively RB69 pol could bury a mismatch in the presence of $\mathrm{Mg}^{2+}$, $\mathrm{Mn}^{2+}$, and $\mathrm{Co}^{2+}$ as this could result in mistakes being preserved during DNA replication if not removed by exo activity or base excision repair. Our choice of DNA containing a dA/dC mismatch $\left(\mathrm{DNA}_{\mathrm{ACMM}}\right)$ and a dA/dG mismatch (DNA $\mathrm{AGMM}$ ) was based on the fact that the $\mathrm{dA} / \mathrm{dC}$ purine-pyrimidine pair has a nascent wobble mispair with the correct size but with distorted geometry while the $\mathrm{dA} / \mathrm{dG}$ represents a purine-purine mispair, which also has distorted geometry but does not form hydrogen bonds between the bases. With $\mathrm{Mg}^{2+}$, the $K_{\mathrm{d} \text {,app }}$ was $800 \mu \mathrm{M}$ and the $k_{\mathrm{pol}}$ was $1 \mathrm{~s}^{-1}$ for extension beyond the $\mathrm{dA} / \mathrm{dC}$ mismatch, indicating that the rate of incorporation of a correct dNMP was very slow compared to the rate of extension past a matched base pair at the primer terminus $\left(>300 \mathrm{~s}^{-1}\right)$. With $\mathrm{Mn}^{2+}$, the $K_{\text {d,app }}$ was $650 \mu \mathrm{M}$, similar to that obtained in the presence of $\mathrm{Mg}^{2+}$, but the $k_{\text {pol }}$ was $17-$ fold higher, demonstrating that the correct dNMP was more readily incorporated beyond the $\mathrm{dA} / \mathrm{dC}$ mismatch. Figure S3A-D shows the plots for incorporation of dAMP opposite dT in the presence of $10 \mathrm{mM} \mathrm{Mg}^{2+}$ and $10 \mathrm{mM} \mathrm{Mn}^{2+}$ at $23{ }^{\circ} \mathrm{C}$. Correct dNMPs can also be incorporated past the $\mathrm{dA} / \mathrm{dC}$ mismatch in the presence of $\mathrm{Co}^{2+}$, but the $K_{\mathrm{d} \text {,app }}$ for dAMP insertion was much higher than those with $\mathrm{Mg}^{2+}$ and $\mathrm{Mn}^{2+}$, resulting in an only 1.8-fold increase in dNMP incorporation efficiency compared to that with $\mathrm{Mg}^{2+}$. The kinetic parameters for extension past a dA/dC mismatch are summarized in Table 4.

Similar results were observed with the $\mathrm{dA} / \mathrm{dG}$ mismatch in the presence of $\mathrm{Mg}^{2+}, \mathrm{Mn}^{2+}$, and $\mathrm{Co}^{2+}$, except that the $K_{\mathrm{d} \text {,app }}$ values for incorporation of dAMP opposite a templating dT were within the same range (300-500 $\mu \mathrm{M})$ (Table 4). The $k_{\text {pol }}$ values for extension past a $\mathrm{dA} / \mathrm{dG}$ mispair were 40-380-fold lower than those obtained with a $\mathrm{dA} / \mathrm{dC}$ mispair. The $k_{\text {pol }} / K_{\mathrm{d} \text {,app }}$ values in the presence of $\mathrm{Co}^{2+}$ and $\mathrm{Mn}^{2+}$ were 10 - and 40 -fold higher than those obtained with $\mathrm{Mg}^{2+}$, respectively, suggesting that these metal ions with RB69pol allow it to more easily extend a primer past a mismatch compared to $\mathrm{Mg}^{2+}$ and hence would be expected to increase the frequency of mistakes during DNA replication. With $\mathrm{Mg}^{2+}, \mathrm{Mn}^{2+}$, and $\mathrm{Co}^{2+}$, the efficiency of bypassing a dA/dG mismatch is approximately $1-2$ orders of magnitude lower than that of extending past a $\mathrm{dA} / \mathrm{dC}$ mismatch. Most of this decrease in efficiency results from a dramatic decrease in $k_{\text {pol }}$ values with $\mathrm{Mg}^{2+}, \mathrm{Co}^{2+}$, and $\mathrm{Mn}^{2+}$, as summarized in Table 4. Figure $\mathrm{S} 4$ shows the plots for incorporation of dAMP opposite dT in the presence of $10 \mathrm{mM} \mathrm{Co}^{2+}$ at $23{ }^{\circ} \mathrm{C}$.

\section{Relative Exonuclease Activity for Exo+ $\mathrm{RB} 69 \mathrm{pol}$ with $\mathrm{Mg}^{2+}, \mathrm{Mn}^{2+}, \mathrm{Co}^{2+}$, and $\mathrm{Ni}^{2+}$}

To test the effect of different metal ions on the exonuclease activity of RB69 pol, we determined the rate of base excision in the presence of $\mathrm{Mg}^{2+}, \mathrm{Co}^{2+}, \mathrm{Mn}^{2+}$, and $\mathrm{Ni}^{2+}$ (Table 
5). The excision rate decreased by 2 - and $\sim 6$-fold when $\mathrm{Mn}^{2+}$ and $\mathrm{Co}^{2+}$, respectively, were substituted for $\mathrm{Mg}^{2+}$. $\mathrm{Ni}^{2+}$ on the other hand diminished the exonuclease activity by a factor of 33-fold as compared to that with $\mathrm{Mg}^{2+}$. Figure $\mathrm{S} 5$ shows the plots for DNA degradation as a function of time in the presence of $10 \mathrm{mM} \mathrm{Ni}^{2+}$ at $23{ }^{\circ} \mathrm{C}$.

\section{$\mathrm{Ca}^{2+}$ Competes with $\mathrm{Mg}^{2+}$ for Metal lon Binding Site(s)}

Wang et al. ${ }^{6}$ have reported the crystal structure of a preinsertion ternary complex of RB69pol containing the $3^{\prime}$-hydroxyl group at the terminus of an extendable primer and a nonhydrolyzable dNTP analogue (dUpXpp; $\mathrm{X}=\mathrm{N}$ or $\mathrm{C}$ ) in the presence of $\mathrm{Ca}^{2+}$ and $\mathrm{Mg}^{2+}$. Because both $\mathrm{Mg}^{2+}$ and $\mathrm{Ca}^{2+}$ can bind to the RB69pol active site, it was expected that $\mathrm{Ca}^{2+}$ could compete with $\mathrm{Mg}^{2+}$ for the metal ion binding site. Competitive inhibition assays were conducted in the presence of $10 \mathrm{mM} \mathrm{Mg}^{2+}$ for the incorporation of dTMP opposite dA in the presence of increasing $\mathrm{Ca}^{2+}$ concentrations. We determined that the $\mathrm{Ca}^{2+}$ concentration required to obtain the half-maximal incorporation rate under single-turnover conditions was $630 \pm 72 \mu \mathrm{M}$, showing that $\mathrm{Ca}^{2+}$ competes with $\mathrm{Mg}^{2+}$ for the metal ion binding site (Figure S6).

\section{Dpo4 and Pol $\beta$ Can Be Activated by $\mathrm{Co}^{2+}$}

Dpo4 is the only DNA polymerase reported to utilize $\mathrm{Ca}^{2+}$, but its incorporation efficiency was much lower than that with $\mathrm{Mg}^{2+.5} \mathrm{Pol} \beta$ and Dpo4 are the only known exceptions to DNA polymerases that are unable to use $\mathrm{Co}^{2+}$ for catalysis. ${ }^{3,5}$ Nevertheless, we decided to ask whether these pols could also employ $\mathrm{Co}^{2+}$ as a cofactor. We showed that $\mathrm{Co}^{2+}$ was competent in the nucleotidyl transfer reaction for both pols under our conditions (Figure 5A, C). When the assay with Dpo4 was repeated under conditions used by Egli et al. (where 2 mM DTT was included in their assays), no primer extension was observed (Figure 5B). Moreover, assays conducted in the absence of any divalent cation served as a negative control. No dNMP incorporation was seen even after incubation for $60 \mathrm{~min}$. The differences between our results with pol $\beta$ and those obtained by Pelletier et al. are addressed in the Discussion. Hence, apart from $\mathrm{Mg}^{2+}$ and $\mathrm{Mn}^{2+}, \mathrm{Co}^{2+}$ can effectively replace $\mathrm{Mg}^{2+}$ for DNA polymerases from different families.

\section{DISCUSSION}

The effect of divalent metal ions on the replication fidelity of various DNA pols has been studied previously, but the rates of incorporation of correct and incorrect nucleotides have not been determined under single-turnover conditions in the presence of different metal ions except for $\mathrm{Mn}^{2+}{ }^{22} \mathrm{Co}^{2+}, \mathrm{Mn}^{2+}$, and $\mathrm{Ni}^{2+}$ have been characterized as "mutagenic", because they reduce the fidelity of DNA synthesis. ${ }^{2,7-11,13}$ Attempts have been made to address the reasons why these metal ions act as mutagens, but most of these studies have focused on the mutagenic behavior of $\mathrm{Mn}^{2+.10,11}$ For example, substitution of $\mathrm{Mn}^{2+}$ for $\mathrm{Mg}^{2+}$ caused an 11-34-fold increase in the rate of misincorporation opposite an abasic site by T4 DNA pol. ${ }^{22}$ $\mathrm{Mn}^{2+}$ also promoted translesion DNA synthesis by herpes simplex virus type $\mathrm{I}^{23} \mathrm{In}$ addition, Pelletier et al. have observed primer extension with pol $\beta$ using blunt-ended DNA in the presence of $\mathrm{Mn}^{2+}$ rather than $\mathrm{Mg}^{2+.3}$ 
Divalent metal ions can alter the fidelity of DNA replication at various points along the reaction pathway by (1) affecting the ground-state binding affinity of correct and incorrect dNTPs for DNA pol/P/T binary complexes,${ }^{24}$ (2) promoting misincorporation during primer extension, ${ }^{2}$ (3) influencing exonuclease activity, ${ }^{23}$ and (4) altering the efficiency of extension beyond a mismatch at the P/T terminus. ${ }^{23}$ Aside from $\mathrm{Mg}^{2+}$, only $\mathrm{Mn}^{2+}, \mathrm{Co}^{2+}$, and $\mathrm{Ni}^{2+}$ can activate $\mathrm{RB} 69$ pol. When $\mathrm{Mg}^{2+}$ was replaced with $\mathrm{Co}^{2+}$, the $k_{\text {pols }}$ for the correct incoming dTTP versus dA or dAP were greater than $300 \mathrm{~s}^{-1}$, whereas with incorrect incoming dNTPs, the $k_{\text {pols }}$ were 3-10 times higher with $\mathrm{Co}^{2+}$ than with $\mathrm{Mg}^{2+}$. The $K_{\mathrm{d} \text {,app }}$ values for the incorrect incoming dNTP were generally higher with $\mathrm{Co}^{2+}$ than with $\mathrm{Mg}^{2+}$, except for dATP versus dC and dTTP versus dC. Because saturation was not achieved with incoming dNTPs for dGTP versus dA and dGTP versus dT, we determined only the $k_{\text {pol }} / K_{\mathrm{d}}$ values. In general, it appears that the level of base discrimination is reduced with $\mathrm{Co}^{2+}$ versus $\mathrm{Mg}^{2+}$ but not nearly as much as when $\mathrm{Mn}^{2+}$ replaced $\mathrm{Mg}^{2+}$, where the $k_{\text {pol }}$ values for the incorporation of incorrect dNMPs were as much as 500 times higher than those found with $\mathrm{Mg}^{2+}$. Surprisingly, a decrease in base selectivity was not observed when $\mathrm{Ni}^{2+}$ was used in place of $\mathrm{Mg}^{2+}$, although the only mismatch tested was dATP versus $\mathrm{dC}$. Lower $K_{\text {d,app }}$ values were observed for most of the mispairs when $\mathrm{Mn}^{2+}$ was substituted for $\mathrm{Mg}^{2+}$ or $\mathrm{Co}^{2+}$, and the largest differences were observed when dAMP was incorporated versus $\mathrm{dC}$ (307 $\mu \mathrm{M}$ for $\mathrm{Mn}^{2+}, 1870 \mu \mathrm{M}$ for $\mathrm{Co}^{2+}$, and $1800 \mu \mathrm{M}$ for $\mathrm{Mg}^{2+}$ ). The exception was when dGMP was inserted opposite dT ( $>2000 \mu \mathrm{M}$ vs $725 \mu \mathrm{M}$ for $\mathrm{Mg}^{2+}$ ); however, the $k_{\text {pol }} / K_{\mathrm{d} \text {,app }}$ for this pair was $1.1 \times 10^{-2} \mu \mathrm{M}^{-1} \mathrm{~s}^{-1}$ for $\mathrm{Mn}^{2+}$ and only $5.6 \times 10^{-5} \mu \mathrm{M}^{-1} \mathrm{~s}^{-1}$ for $\mathrm{Mg}^{2+}$, which was why the level of base discrimination for dGTPs versus dT was so dramatically reduced with $\mathrm{Mn}^{2+}$. It is also worth noting that the efficiency of correct insertions (dTMP vs dA or dAP) when assayed at $6{ }^{\circ} \mathrm{C}$ instead of $23{ }^{\circ} \mathrm{C}$ was greatest for $\mathrm{Co}^{2+}$ compared to those with $\mathrm{Mn}^{2+}$ and $\mathrm{Mg}^{2+}$ (Table 2).

With respect to ground-state binding affinities for dTTP versus dAP as measured by $2 \mathrm{AP}$ fluorescence quenching, $\mathrm{Mn}^{2+}-\mathrm{RB} 69 \mathrm{pol}$ complexes had the lowest dissociation constant $\left(K_{\mathrm{dg}}\right)$, almost equal to that of complexes containing $\mathrm{Ca}^{2+}$ followed by $\mathrm{Co}^{2+}$ and then $\mathrm{Mg}^{2+}$. For an incorrect dNTP (dCTP vs dAP), the $K_{\mathrm{dg}}$ differences were much greater between $\mathrm{Mg}^{2+}$ and $\mathrm{Mn}^{2+}$ (1400 and 34) (Table 3), consistent with the enhanced ability of dCMP to be inserted opposite $2 \mathrm{AP}$ by $\mathrm{Mn}^{2+}$ compared to $\mathrm{Mg}^{2+}$ (Table 1 ). This might be due to the ability of $\mathrm{Mn}^{2+}$, in contrast to $\mathrm{Mg}^{2+}$, to accommodate nucleotide residues other than the four normal bases in the nucleotide binding pocket for reasons discussed below.

As far as the ability of the various divalent cations to promote the nucleophilicity of the primer's $3^{\prime}-\mathrm{OH}$ is concerned, their effect on reducing the $\mathrm{p} K_{\mathrm{a}}$ of bound water is about the same for $\mathrm{Mg}^{2+}$ and $\mathrm{Mn}^{2+}$ but considerably lower for $\mathrm{Co}^{2+}$ (Table 6). If this was the main effect responsible for differences in $k_{\text {pol }}$, then $\mathrm{Co}^{2+}$ and $\mathrm{Ni}^{2+}$ would be expected to be more effective than $\mathrm{Mg}^{2+}$ and $\mathrm{Mn}^{2+}$, which was not the case. Apart from activating the $3^{\prime}$ hydroxyl group, the ionic radius of metal ion A plays a crucial role in determining the proximal distance between the $3^{\prime}$-hydroxyl group and $a$-phosphorus atom of the incoming dNTP as the transition state is approached. The ionic radius of $\mathrm{Mg}^{2+}$ is $0.86 \AA$, while those of $\mathrm{Mn}^{2+}, \mathrm{Co}^{2+}$, and $\mathrm{Ni}^{2+}$ are $0.81,0.89$, and $0.83 \AA$, respectively, values very close to that of $\mathrm{Mg}^{2+}$, allowing all these metal ions to bring the $3^{\prime}$-hydroxyl group and $a$-phosphate atom of the incoming dNTP close enough for reaction (Table 6). In addition, the coordination 
geometry of metal ions A and B plays a crucial role in the nucleotidyl transfer reaction. Wang et al. ${ }^{6}$ have reported the crystal structure of a preinsertion ternary complex of RB69pol containing the $3^{\prime}$-hydroxyl group at the terminus of an extendable primer and a nonhydrolyzable dUTP analogue $\left(\mathrm{dU}_{\mathrm{p}} \mathrm{N}_{\mathrm{pp}}\right)$ in the presence of $\mathrm{Ca}^{2+}, \mathrm{Mg}^{2+}$, and $\mathrm{Mn}^{2+} \cdot \mathrm{Mg}^{2+}$ in the $\mathrm{B}$ metal ion site exhibits a nearly perfect octahedral geometry, and $\mathrm{Mg}^{2+}$ in the A site shows a distorted octahedral geometry. Similar to $\mathrm{Mg}^{2+}, \mathrm{Mn}^{2+}$ in the $\mathrm{B}$ metal ion site exhibits a nearly perfect octahedral geometry and $\mathrm{Mn}^{2+}$ in the A metal site also exhibits a distorted octahedral geometry caused by the displacement of the $3^{\prime}$-hydroxyl group at the $3^{\prime}$-terminus of the primer. Also, both $\mathrm{Mn}^{2+}$ and $\mathrm{Mg}^{2+}$ (in the B site) form an $a, \beta, \gamma$ tridentate complex with the triphosphate tail of $\mathrm{dU}_{\mathrm{p}} \mathrm{N}_{\mathrm{pp}}{ }^{6}$ In addition to $\mathrm{Mg}^{2+}$ and $\mathrm{Mn}^{2+}$, $\mathrm{Co}^{2+}$ and $\mathrm{Ni}^{2+}$ are also able to form octahedral complexes, ${ }^{25}$ and even though crystal structures of RB69pol with these metal ions are not currently available, it is likely that $\mathrm{Co}^{2+}$ binds in a fashion similar to that of $\mathrm{Mg}^{2+}$ in the $\mathrm{A}$ and $\mathrm{B}$ sites. The observation that only $\mathrm{Co}^{2+}, \mathrm{Mn}^{2+}$, and $\mathrm{Ni}^{2+}$ are able to activate $\mathrm{RB} 69 \mathrm{pol}$ is consistent with (1) the similar ionic radii of these metal ions compared to that of $\mathrm{Mg}^{2+}$, (2) the formation of octahedral complexes as found with $\mathrm{Mg}^{2+}, 25$ and (3) their ability to lower the $\mathrm{p} K_{\mathrm{a}}$ of the $3^{\prime}$-hydroxyl group of the primer.

It has been reported that $\mathrm{Ca}^{2+}$ does not act as a metal ion cofactor for $\mathrm{RB} 69$ pol. ${ }^{6} \mathrm{Ca}^{2+}$ is not able to effectively lower the $\mathrm{p} K_{\mathrm{a}}$ of the $3^{\prime}$-hydroxyl group of the primer (12.8) compared to $\mathrm{Mg}^{2+}$ (11.4), and the ionic radius of $\mathrm{Ca}^{2+}(1.1 \AA)$ is significantly larger than that of $\mathrm{Mg}^{2+}(0.86 \AA)$. Thus, $\mathrm{Ca}^{2+}$ is ineffective in polarizing the hydroxyl group for nucleophilic attack. Also, crystal structures of RB69pol ternary complexes show that $\mathrm{Ca}^{2+}$ is displaced toward the $3^{\prime}$-hydroxyl group of the primer terminus. ${ }^{6} \mathrm{As}$ a result, $\mathrm{Ca}^{2+}$ is unable to bring the $3^{\prime}$-hydroxyl group close enough to the $a$-phosphorus atom of the incoming dNTP for nucleotidyl transfer.

The mutagenic behavior of $\mathrm{Mn}^{2+}$ has been rationalized on the basis of the fact that $\mathrm{Mg}^{2+}$ is considered a harder metal ion than $\mathrm{Mn}^{2+}$, implying that $\mathrm{Mn}^{2+}$ is somewhat more polarizable than $\mathrm{Mg}^{2+.26}$ When $\mathrm{Mg}^{2+}$ or $\mathrm{Mn}^{2+}$ is in a hexahydrated complex $\left(\mathrm{Mn}\left[\mathrm{H}_{2} \mathrm{O}\right]_{6}{ }^{2+}\right.$ or $\mathrm{Mg}\left[\mathrm{H}_{2} \mathrm{O}\right]_{6}{ }^{2+}$, respectively) and the inner sphere coordination number is changed from 6 to 5 to 4 , there is a greater energy penalty with $\mathrm{Mg}^{2+}$ than with $\mathrm{Mn}^{2+}$, indicating less rigid coordination requirements for $\mathrm{Mn}^{2+}$ complexes that would allow more freedom for mismatched dNTPs to be accessible to the nucleotide binding pocket. ${ }^{26}$ Pelletier et al. ${ }^{3}$ have suggested that because transition metal ions bind more tightly to carboxylate groups and the triphosphate moiety of dNTPs than $\mathrm{Mg}^{2+}$ does, this difference could account for the decrease in base selectivity in the presence of $\mathrm{Mn}^{2+}$.

\section{Primer Extension past $\mathrm{dA} / \mathrm{dC}$ and $\mathrm{dA} / \mathrm{dG}$ Mismatches}

Extension beyond a mismatch at a P/T terminus can contribute to the number of errors in the nascent DNA. ${ }^{27}$ When we investigated the influence of three of the four active metal ions $\left(\mathrm{Mg}^{2+}, \mathrm{Mn}^{2+}\right.$, and $\left.\mathrm{Co}^{2+}\right)$ on the efficiency of extending a primer beyond a mismatch at the primer terminus, it was clear that $\mathrm{Mn}^{2+}$ was much more effective than $\mathrm{Mg}^{2+}$ mainly because of the higher $k_{\text {pol }}$ values (Table 4) observed with $\mathrm{Mn}^{2+}, \mathrm{Co}^{2+}$ was also able to serve as an activating cation in this reaction with $k_{\text {pol }}$ values for Pur/Pyr mismatches at the primer 
terminus that were similar to those observed with $\mathrm{Mn}^{2+}$, but the $K_{\mathrm{d} \text {,app }}$ with $\mathrm{Co}^{2+}$ was greater than $2 \mathrm{mM}$ in contrast to those with $\mathrm{Mg}^{2+}$ and $\mathrm{Mn}^{2+}$. Without a crystal structure for this ternary complex, we are unable to provide a structural rationale for this result. On the other hand, when there was a Pur/Pur mismatch that had to be extended by RB69pol with $\mathrm{Co}^{2+}$, the $K_{\mathrm{d} \text {,app }}$ values were in the same range as that found with $\mathrm{Mg}^{2+}$ and $\mathrm{Mn}^{2+}$. In this situation, the $k_{\text {pol }}$ for primer extension was 10 times higher than the $k_{\text {pol }}$ observed with $\mathrm{Mg}^{2+}$.

\section{Effect of the Active Metal lons on the Exonculease Activity of RB69pol}

As shown in Table $5, \mathrm{Mg}^{2+}$ was the most active cation for promoting base excision, but the difference among $\mathrm{Mg}^{2+}, \mathrm{Mn}^{2+}$, and $\mathrm{Co}^{2+}$ was not that great. $\mathrm{Ni}^{2+}$ supported the exo activity, but it was much less effective than the other metal ions. In contrast to our results, the $3^{\prime}-5^{\prime}$ exonuclease activity of T4 DNA polymerase was reported to be unaffected by substitution of $\mathrm{Mn}^{2+}$ for $\mathrm{Mg}^{2+.23}$ Also, the rates of base excision with $\mathrm{Mg}^{2+}(2 \mathrm{mM}), \mathrm{Mn}^{2+}(4 \mathrm{mM})$, and $\mathrm{Co}^{2+}(4 \mathrm{mM})$ were nearly identical for $E$. coli DNA pol I. ${ }^{8}$ Clearly, divalent cations affect the exonuclease activity of pols, but the differences are minor compared to their influence on misincorporation.

\section{Comparison of Preferences of Metal lons for Different DNA Polymerases}

All DNA polymerases known to date utilize $\mathrm{Mg}^{2+}$ as a cofactor. Most pols can also use $\mathrm{Mn}^{2+}$ and $\mathrm{Co}^{2+}$, albeit with reduced fidelity. ${ }^{8-10,13}$ There are two known exceptions, namely, human pol $\beta^{3}$ and Dpo $4,{ }^{5}$ which cannot be activated by $\mathrm{Co}^{2+}$. However, under our experimental conditions, both of these pols allowed primer extension with $\mathrm{Co}^{2+}$. This apparent discrepancy might be explained by the different assay conditions. Pelletier et al. ${ }^{3}$ used blunt-ended DNA for their crystal soaking experiments with pol $\beta$ complexed with DNA where the templating base is absent, ${ }^{3}$ while we used a P/T containing dA as the templating base. With Dpo4, Egli et al. ${ }^{5}$ used 2 mM DTT in their extension assays; however, DTT is a strong reducing agent (standard electrode potential of $-0.33 \mathrm{~V}$ ) ${ }^{25}$ and is capable of reducing $\mathrm{Co}^{2+}$ because the standard reduction potential for $\mathrm{Co}^{2+}$ is $-0.28 \mathrm{~V}$. This could explain the absence of extension products observed by these authors as opposed to our conditions where DTT was absent and primer extension was observed (Figure 5C).

Studies of pol $\beta$ have shown that $\mathrm{Zn}^{2+}$ and $\mathrm{Cd}^{2+}$ were active ${ }^{3}$ while $\mathrm{RB} 69$ pol was not able to use either one of these metal ions for catalysis. $\mathrm{Ni}^{2+}$ can support catalysis for all DNA polymerases, albeit with greatly reduced activity except for human pol $a,{ }^{28}$ human pol $\beta,{ }^{3}$ and Dpo4. ${ }^{5}$ Moreover, Dpo4 is the only polymerase that can utilize $\mathrm{Ca}^{2+}$ as a cofactor, although $\mathrm{Ca}^{2+}$ is much less active than $\mathrm{Mg}^{2+.5}$ Clearly, DNA polymerases from different families have different metal ion cofactor preferences in addition to $\mathrm{Mg}^{2+}$, which is universally active. This suggests that size, charge, coordination geometry, and the ability to lower the $\mathrm{p} K_{\mathrm{a}}$ of the primer's $3^{\prime}-\mathrm{OH}$ group are not the only determinants of metal ion specificity. Our results extend the information obtained from previous studies that have been conducted to elucidate the role of different metal ions in the replication fidelity of different DNA polymerases. 


\section{Supplementary Material}

Refer to Web version on PubMed Central for supplementary material.

\section{Acknowledgments}

Funding

This work was supported by a grant (GM063276-9) from the National Institutes of Health (to W.H.K.).

We thank Wei Yang for Dpo4-overexpressing plasmid RW382 and Samuel Wilson for providing purified pol $\beta$. We also thank Dr. Paul F. Cook, Thomas Christian, and Shuangluo Xia for helpful comments on the manuscript.

\section{ABBREVIATIONS}

\begin{tabular}{|c|c|}
\hline $\mathbf{2 A P}$ & 2-aminopurine \\
\hline RB69pol & bacteriophage RB69 DNA polymerase \\
\hline dNTP & deoxynucleoside triphosphate \\
\hline Dpo4 & DNA polymerase IV from Sulfolobus solfataricus \\
\hline $\mathbf{e x o}^{-}$ & DNA polymerase lacking the exonuclease proofreading activity \\
\hline $\mathbf{e x o}^{+}$ & DNA polymerase exhibiting both the polymerase and exonuclease activities \\
\hline$k_{\text {obs }}$ & observed rate constant \\
\hline$k_{\text {pol }}$ & maximal rate of dNMP incorporation \\
\hline$K_{\mathrm{d}, \mathbf{a p p}}$ & $\begin{array}{l}\text { apparent equilibrium dissociation constant for dNTP that supports the half- } \\
\text { maximal rate of dNMP incorporation }\end{array}$ \\
\hline$K_{\mathrm{d}, \mathrm{g}}$ & $\begin{array}{l}\text { ground-state equilibrium dissociation constant for an incoming dNTP from a } \\
\text { DNA pol-DNA-dNTP ternary complex }\end{array}$ \\
\hline MES & 2-( $N$-morpholino)-ethanesulfonic acid \\
\hline pol & polymerase \\
\hline
\end{tabular}

\section{References}

1. Drake JW. Comparative rates of spontaneous mutation. Nature. 1969; 221:1132. [PubMed: 4378427]

2. Vaisman A, Ling H, Woodgate R, Yang W. Fidelity of Dpo4: effect of metal ions, nucleotide selection and pyrophosphorolysis. EMBO J. 2005; 24:2957-2967. [PubMed: 16107880]

3. Pelletier H, Sawaya MR, Wolfle W, Wilson SH, Kraut J. A structural basis for metal ion mutagenicity and nucleotide selectivity in human DNA polymerase beta. Biochemistry. 1996; 35:12762-12777. [PubMed: 8841119]

4. Irimia A, Loukachevitch LV, Eoff RL, Guengerich FP, Egli M. Metal-ion dependence of the activesite conformation of the translesion DNA polymerase Dpo4 from Sulfolobus solfataricus. Acta Crystallogr, Sect F: Struct Biol Cryst Commun. 2010; 66:1013-1018. 
5. Irimia A, Zang H, Loukachevitch LV, Eoff RL, Guengerich FP, Egli M. Calcium is a cofactor of polymerization but inhibits pyrophosphorolysis by the Sulfolobus solfataricus DNA polymerase Dpo4. Biochemistry. 2006; 45:5949-5956. [PubMed: 16681366]

6. Xia S, Wang M, Blaha G, Konigsberg WH, Wang J. Structural Insights into Complete Metal Ion Coordination from Ternary Complexes of B Family RB69 DNA Polymerase. Biochemistry. 2011; 50:9114-9124. [PubMed: 21923197]

7. Snow ET, Xu LS, Kinney PL. Effects of nickel ions on polymerase activity and fidelity during DNA replication in vitro. Chem-Biol Interact. 1993; 88:155-173. [PubMed: 8403077]

8. Sirover MA, Dube DK, Loeb LA. On the fidelity of DNA replication. Metal activation of Escherichia coli DNA polymerase I. J Biol Chem. 1979; 254:107-111. [PubMed: 363715]

9. Sirover MA, Loeb LA. On the fidelity of DNA replication. Effect of metal activators during synthesis with avian myeloblastosis virus DNA polymerase. J Biol Chem. 1977; 252:3605-3610. [PubMed: 863897]

10. Miyaki M, Murata I, Osabe M, Ono T. Effect of metal cations on misincorporation by E. coli DNA polymerases. Biochem Biophys Res Commun. 1977; 77:854-860. [PubMed: 332171]

11. Goodman MF, Keener S, Guidotti S, Branscomb EW. On the enzymatic basis for mutagenesis by manganese. J Biol Chem. 1983; 258:3469-3475. [PubMed: 6833210]

12. Vashishtha AK, Kuchta RD. Polymerase and exonuclease activities in herpes simplex virus type 1 DNA polymerase are not highly coordinated. Biochemistry. 2015; 54:240-249. [PubMed: 25517265]

13. Sirover MA, Loeb LA. Infidelity of DNA synthesis in vitro: screening for potential metal mutagens or carcinogens. Science. 1976; 194:1434-1436. [PubMed: 1006310]

14. Wang CX, Zakharova E, Li J, Joyce CM, Wang J, Konigsberg W. Pre-steady-state kinetics of RB69 DNA polymerase and its exo domain mutants: effect of $\mathrm{pH}$ and thiophosphoryl linkages on $3^{\prime}-5^{\prime}$ exonuclease activity. Biochemistry. 2004; 43:3853-3861. [PubMed: 15049692]

15. Xia S, Vashishtha A, Bulkley D, Eom SH, Wang J, Konigsberg WH. Contribution of partial charge interactions and base stacking to the efficiency of primer extension at and beyond abasic sites in DNA. Biochemistry. 2012; 51:4922-4931. [PubMed: 22630605]

16. Kuchta RD, Mizrahi V, Benkovic PA, Johnson KA, Benkovic SJ. Kinetic mechanism of DNA polymerase I (Klenow). Biochemistry. 1987; 26:8410-8417. [PubMed: 3327522]

17. Zhang H, Rhee C, Bebenek A, Drake JW, Wang J, Konigsberg W. The L561A substitution in the nascent base-pair binding pocket of RB69 DNA polymerase reduces base discrimination. Biochemistry. 2006; 45:2211-2220. [PubMed: 16475809]

18. Boudsocq F, Kokoska RJ, Plosky BS, Vaisman A, Ling H, Kunkel TA, Yang W, Woodgate R. Investigating the role of the little finger domain of Y-family DNA polymerases in low fidelity synthesis and translesion replication. J Biol Chem. 2004; 279:32932-32940. [PubMed: 15155753]

19. Wang M, Lee HR, Konigsberg W. Effect of A and B metal ion site occupancy on conformational changes in an RB69 DNA polymerase ternary complex. Biochemistry. 2009; 48:2075-2086. [PubMed: 19228037]

20. Wang TS, Sedwick WD, Korn D. Nuclear deoxyribonucleic acid polymerase. Purification and properties of the homogeneous enzyme from human KB cells. J Biol Chem. 1974; 249:841-850. [PubMed: 4359770]

21. Seal G, Shearman CW, Loeb LA. On the fidelity of DNA replication. Studies with human placenta DNA polymerases. J Biol Chem. 1979; 254:5229-5237. [PubMed: 447644]

22. Hays H, Berdis AJ. Manganese substantially alters the dynamics of translesion DNA synthesis. Biochemistry. 2002; 41:4771-4778. [PubMed: 11939771]

23. Villani G, Tanguy Le Gac N, Wasungu L, Burnouf D, Fuchs RP, Boehmer PE. Effect of manganese on in vitro replication of damaged DNA catalyzed by the herpes simplex virus type-1 DNA polymerase. Nucleic Acids Res. 2002; 30:3323-3332. [PubMed: 12140316]

24. Lee HR, Wang M, Konigsberg W. The reopening rate of the fingers domain is a determinant of base selectivity for RB69 DNA polymerase. Biochemistry. 2009; 48:2087-2098. [PubMed: 19228036]

25. Cotton, FA., Wilkinson, G., Murillo, CA., Bochmann, M. Advanced Inorganic Chemistry. 6. John Wiley \& Sons; New York: 1999. 
26. Bock CW, Katz AK, MArkham GD, Glusker JP. Manganese as a Replacement for Manganese and Zinc: Functional Comparison of the Divalent ions. J Am Chem Soc. 1999; 121:7360-7372.

27. Yu SL, Lee SK, Johnson RE, Prakash L, Prakash S. The stalling of transcription at abasic sites is highly mutagenic. Mol Cell Biol. 2003; 23:382-388. [PubMed: 12482989]

28. Chin YE, Snow ET, Cohen MD, Christie NT. The effect of divalent nickel $\left(\mathrm{Ni}^{2+}\right)$ on in vitro DNA replication by DNA polymerase alpha. Cancer Res. 1994; 54:2337-2341. [PubMed: 8162578] 


$$
\begin{aligned}
& \text { DNA }_{13 \mathrm{~T}} \quad 5^{\prime}-\text { GC GGA CTG CTT AC-3' } \\
& \text { 3'-GCG CCT GAC GAA TGT CCT-5' } \\
& \text { DNA }_{13 \mathrm{~A}} \quad 5^{\prime}-\text { GC GGA CTG CTT AC-3' } \\
& \text { 3'-GCG CCT GAC GAA TGA CCT-5' } \\
& \text { DNA }_{13 G} \quad 5^{\prime}-\text { GC GGA CTG CTT AC-3' } \\
& \text { 3'-GCG CCT GAC GAA TGG CCT-5' } \\
& \text { DNA }_{13 \mathrm{C}} \quad 5^{\prime}-\mathrm{GC} \text { GGA CTG CTT AC-3' } \\
& \text { 3'-GCG CCT GAC GAA TGC CCT-5' } \\
& \text { DNAP }_{P} \quad 5^{\prime}-\text { GC GGA CTG CTT AC-3' } \\
& \text { 3'-GCG CCT GAC GAA TGP CCT-5' } \\
& \text { DNA }_{\text {Pdd }} \quad 5^{\prime}-\text { GC GGA CTG CTT A. } \underline{C d d}_{d d^{\prime}} \\
& \text { 3'-GCG CCT GAC GAA TGP CCT-5' } \\
& \text { DNA }_{\text {ACMM }} \quad 5^{\prime}-\text { GC GGA CTG CTT AA-3' } \\
& \text { 3'-GCG CCT GAC GAA TCT CCT-5' } \\
& \text { DNA }_{\text {AGMM }} \quad 5^{\prime}-\text { GC GGA CTG CTT AA-3' } \\
& \text { 3'-GCG CCT GAC GAA TGT CCT-5' }
\end{aligned}
$$

Figure 1.

Primer/template sequences used for the pre-steady-state kinetic assays and equilibrium fluorescence titrations. The templating base is shown in bold. P represents 2-aminopurine as the templating base; $\mathrm{C}$ represents the dideoxy-terminated cytosine. 
A

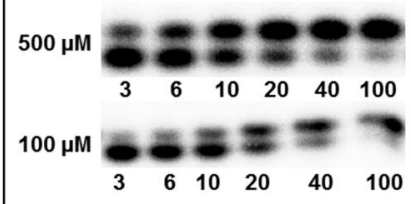

$25 \mu \mathrm{M}$

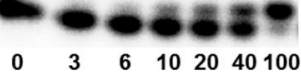

Time (ms)

B

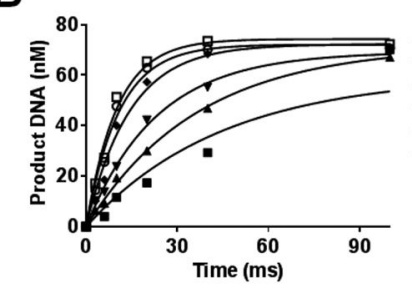

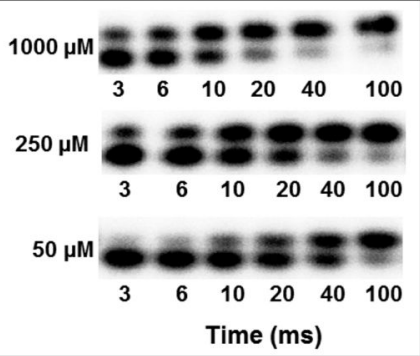

C

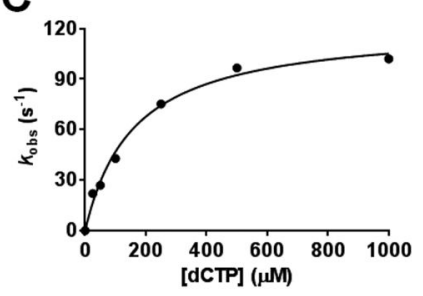

Figure 2.

Concentration dependence of the rate of incorporation of dCTP opposite 2AP as the templating base. RB69pol $(1 \mu \mathrm{M})$ was preincubated with $\mathrm{DNA}_{\mathrm{P}}(80 \mathrm{nM})$ in reaction buffer and was mixed with increasing concentrations of $\operatorname{dCTP}(25,50,100,250,500$, and 1000 $\mu \mathrm{M}$ ) containing $10 \mathrm{mM} \mathrm{Mn}^{2+}$. Reactions were quenched with $0.5 \mathrm{M}$ EDTA (pH 8.0) at various times ranging from 3 to $100 \mathrm{~ms}$. All data were obtained at $23{ }^{\circ} \mathrm{C}$. (A) Gel images showing incorporation of dCMP opposite dAP at various dCTP concentrations. (B) Plots of the amount of extended DNA product obtained as a function of time at various dCTP concentrations. Points are experimental, while curves are based on a fit of the data to eq 1 . (C) Single-exponential rates plotted as a function of dCTP concentration and fitted to eq 2 to obtain a $K_{\text {pol }}$ of $122 \pm 5 \mathrm{~s}^{-1}$ and a $K_{\mathrm{d} \text {,app }}$ of $160 \pm 22 \mu \mathrm{M}$. 
A

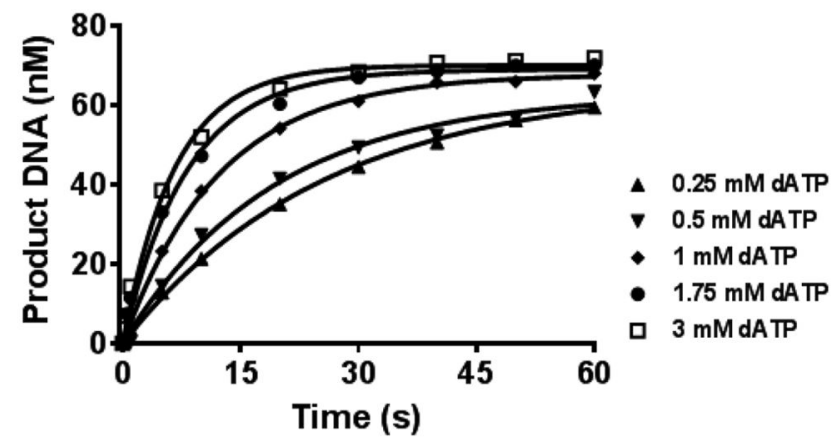

B

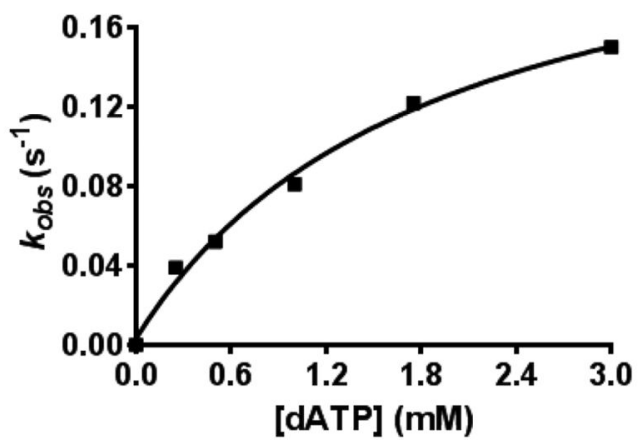

Figure 3.

Concentration dependence of the rate of incorporation of dATP opposite $\mathrm{dC}$ as the templating base. RB69pol $(1 \mu \mathrm{M})$ was preincubated with $\mathrm{DNA}_{\mathrm{C}}(80 \mathrm{nM})$ in reaction buffer and was mixed with increasing concentrations of dATP $(0.25,0.50,1,1.75$, and $3 \mathrm{mM})$ containing $10 \mathrm{mM} \mathrm{Co}^{2+}$. Reactions were quenched with $0.5 \mathrm{M}$ EDTA (pH 8.0) at various times ranging from 0.5 to $60 \mathrm{~s}$. All data were obtained at $23{ }^{\circ} \mathrm{C}$. (A) Gel images showing incorporation of dAMP opposite $\mathrm{dC}$ at various dATP concentrations. (B) Plots of the amount of extended DNA product obtained as a function of time at various dATP concentrations. Points are experimental, while curves are based on a fit of the data to eq 1. (C) Singleexponential rates plotted as a function of dATP concentration and fitted to eq 2 to obtain a $k_{\text {pol }}$ of $0.23 \pm 0.02 \mathrm{~s}^{-1}$ and a $K_{\mathrm{d}, \text { app }}$ of $1.87 \pm 0.52 \mathrm{mM}$. 
A

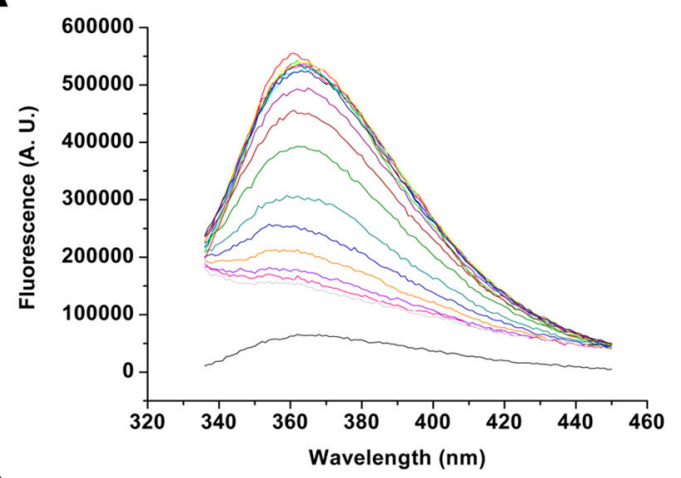

B

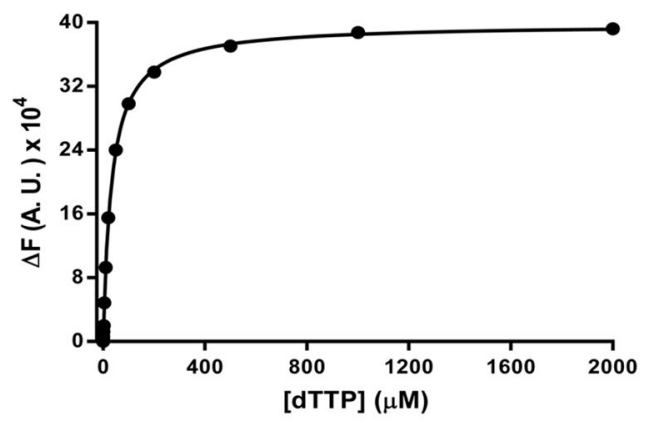

Figure 4.

Equilibrium fluorescence titration of the RB69pol-ddP/T complex with increasing dTTP concentrations. (A) Fluorescence emission spectra of the RB69pol-ddP/T-dTTP complex are shown as solid lines in the presence of $10 \mathrm{mM} \mathrm{MgCl}_{2}$. The concentration of DNA Pdd was $200 \mathrm{nM}$, and that of RB69pol was $1 \mu \mathrm{M}$. The dTTP concentrations were $0,0.02,0.04$, $0.1,0.25,0.5,1,2,5,10,20,50,100,200,500,1000$, and $2000 \mu \mathrm{M}$ (from top to bottom, respectively). The solid black line at the bottom is the fluorescence spectrum of DNAPdd alone. (B) Fluorescence intensities at $365 \mathrm{~nm}$ fitted to a hyperbolic equation. Titration of dTTP vs $2 \mathrm{AP}$ in the presence of $10 \mathrm{mM} \mathrm{MgCl}_{2}$ gives a $K_{\mathrm{d}, \mathrm{g}}$ of $34 \pm 1 \mu \mathrm{M}$. $\Delta F$ represents the change in fluorescence in the direction of quenching, and $\Delta F$ increases with an increase in dTTP concentration. 

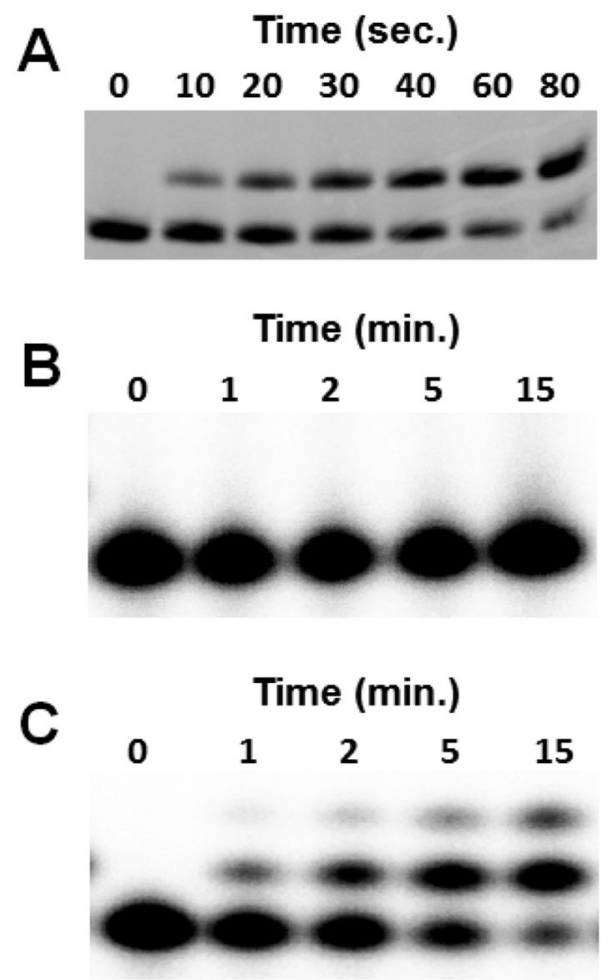

Figure 5.

$\mathrm{Co}^{2+}$ can be utilized as a cofactor for pol $\beta$ and Dpo4. Pol $\beta(1 \mu \mathrm{M})$ was incubated with 80 $\mathrm{nM} \mathrm{DNA}_{13 \mathrm{~A}}$ and $1 \mathrm{mM}$ dTTP in buffer containing $10 \mathrm{mM} \mathrm{Co}^{2+}$, and aliquots were withdrawn at the noted times. Dpo4 $(20 \mathrm{nM})$ was incubated with $1 \mu \mathrm{M} \mathrm{DNA}_{13 \mathrm{~A}}$ and $1 \mathrm{mM}$ dTTP in buffer containing $10 \mathrm{mM} \mathrm{Co}^{2+}$, and aliquots were withdrawn at the noted times. (A) Gel images of the products of $\mathrm{DNA}_{13 \mathrm{~A}}$ (fluorescein-labeled $5^{\prime}$-end primer) extension using pol $\beta$ at various times. (B) Phosphorimages of the products of $\mathrm{DNA}_{13 \mathrm{~A}}$ extension using Dpo4 in the presence of $2 \mathrm{mM}$ DTT at various times. (C) Phosphorimages of the products of DNA $_{13 \mathrm{~A}}$ extension using Dpo4 in the absence of $2 \mathrm{mM}$ DTT at various times. 


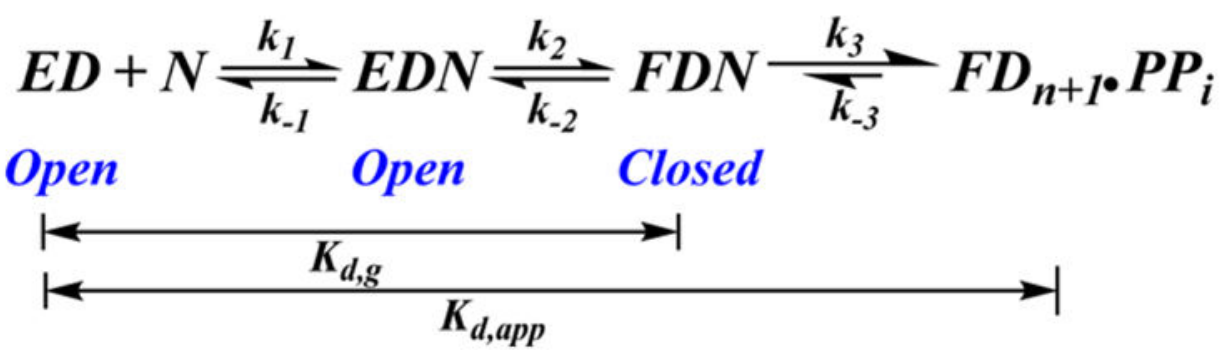

Scheme 1. Minimal Kinetic Scheme Depicting the Ground-State Binding Affinity $\left(K_{\mathbf{d}, \mathrm{g}}\right)$ and Apparent Binding Affinity $\left(K_{\mathrm{d}, \mathrm{app}}\right)$ for an Incoming $\mathrm{dNTP}^{a}$

${ }^{a} \mathrm{EDN}$ represents the open conformation of the ternary complex, whereas FDN represents the closed conformation. 


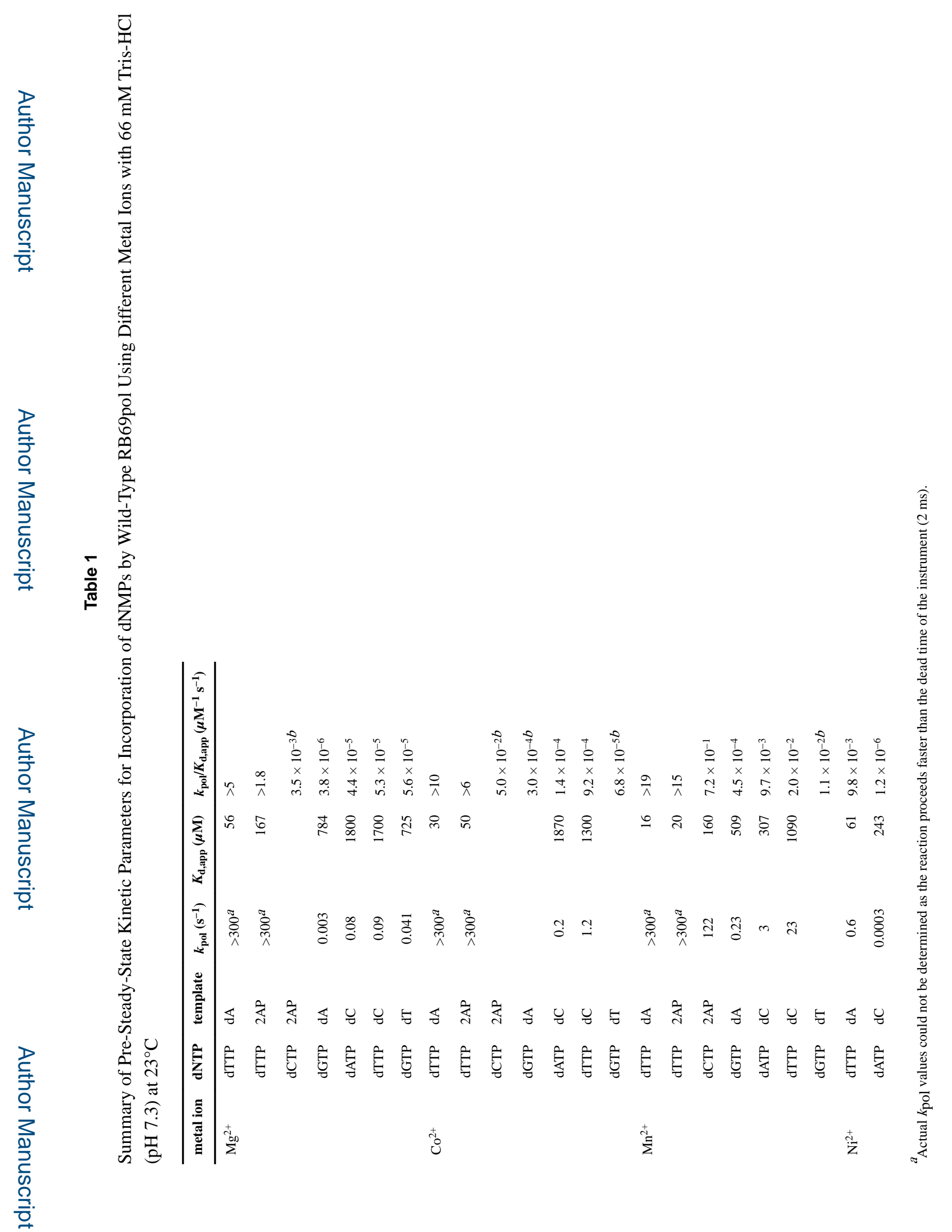




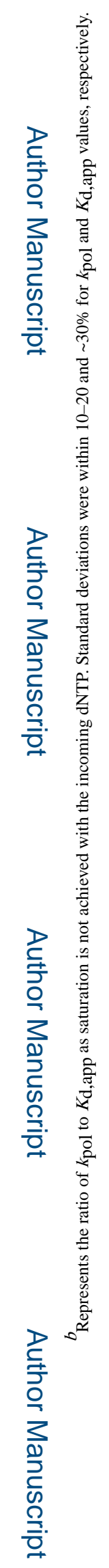




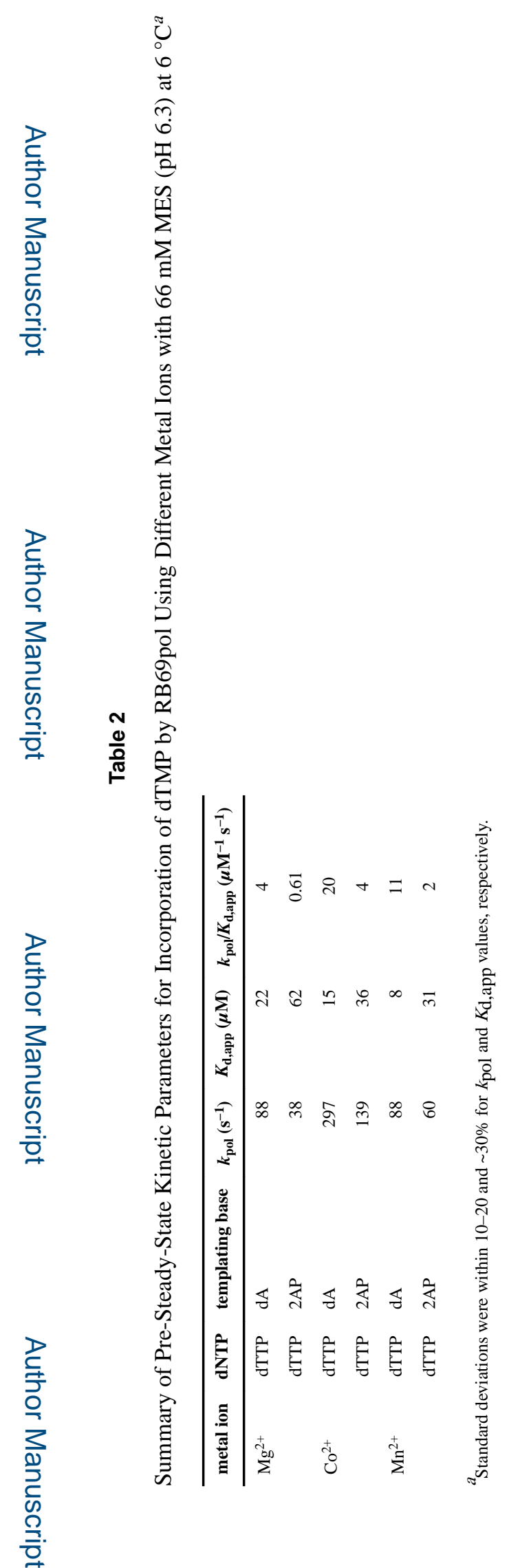

Biochemistry. Author manuscript; available in PMC 2018 June 06. 


\section{Table 3}

Equilibrium Fluorescence Titration Data for RB69pol Using $\mathrm{Mg}^{2+}, \mathrm{Co}^{2+}, \mathrm{Mn}^{2+}$, and $\mathrm{Ca}^{2+}$ with $2 \mathrm{AP}$ as the Templating Base $^{a}$

\begin{tabular}{|c|c|c|c|c|}
\hline metal ion & $\mathbf{P} / \mathbf{T}$ & dNTP & $K_{\mathrm{d}, \mathrm{g}}(\mu \mathrm{M})$ & quench amplitude (\%) \\
\hline $\mathrm{Mg}^{2+}$ & $\mathrm{ddP} / \mathrm{T}$ & dTTP & 34 & 68 \\
\hline $\mathrm{Mg}^{2+}$ & $\mathrm{ddP} / \mathrm{T}$ & $\mathrm{dCTP}$ & 1400 & 72 \\
\hline $\mathrm{Co}^{2+}$ & $\mathrm{ddP} / \mathrm{T}$ & dTTP & 6.0 & 72 \\
\hline $\mathrm{Co}^{2+}$ & $\mathrm{ddP} / \mathrm{T}$ & $\mathrm{dCTP}$ & $\mathrm{ND}^{b}$ & \\
\hline $\mathrm{Mn}^{2+}$ & $\mathrm{ddP} / \mathrm{T}$ & dTTP & 0.6 & 65 \\
\hline $\mathrm{Mn}^{2+}$ & $\mathrm{ddP} / \mathrm{T}$ & $\mathrm{dCTP}$ & 34 & 63 \\
\hline $\mathrm{Ca}^{2+}$ & $\mathrm{dP} / \mathrm{T}$ & dTTP & 0.17 & 26 \\
\hline $\mathrm{Ca}^{2+}$ & $\mathrm{ddP} / \mathrm{T}$ & dTTP & 0.44 & 75 \\
\hline $\mathrm{Ca}^{2+}$ & $\mathrm{ddP} / \mathrm{T}$ & $\mathrm{dCTP}$ & 14 & 46 \\
\hline
\end{tabular}




\section{Table 4}

Pre-Steady-State Kinetic Parameters for Extension beyond dA/dC, and dA/dG Mismatches for RB69pol Using $\mathrm{Mg}^{2+}, \mathrm{Co}^{2+}$, and $\mathrm{Mn}^{2+}$, Where dAMP Is Being Inserted opposite a Templating dT

\begin{tabular}{lclcl}
\hline metal ion & P/T mismatch & $\boldsymbol{k}_{\text {pol }}\left(\mathbf{s}^{-\mathbf{1}}\right)$ & $\boldsymbol{K}_{\text {d,app }}(\boldsymbol{\mu} \mathbf{M})$ & $\boldsymbol{k}_{\text {pol }} / \boldsymbol{K}_{\text {d,app }}\left(\boldsymbol{\mu} \mathbf{M}^{-1} \mathbf{s}^{-\mathbf{1}}\right)$ \\
\hline $\mathrm{Mg}^{2+}$ & $\mathrm{dA} / \mathrm{dC}$ & 1 & 800 & $1.2 \times 10^{-3}$ \\
$\mathrm{Mg}^{2+}$ & $\mathrm{dA} / \mathrm{dG}$ & 0.006 & 350 & $1.7 \times 10^{-5}$ \\
$\mathrm{Co}^{2+}$ & $\mathrm{dA} / \mathrm{dC}$ & & & $2.2 \times 10^{-3 a}$ \\
$\mathrm{Co}^{2+}$ & $\mathrm{dA} / \mathrm{dG}$ & 0.05 & 310 & $1.7 \times 10^{-4}$ \\
$\mathrm{Mn}^{2+}$ & $\mathrm{dA} / \mathrm{dC}$ & 17 & 650 & $2.6 \times 10^{-2}$ \\
$\mathrm{Mn}^{2+}$ & $\mathrm{dA} / \mathrm{dG}$ & 0.37 & 500 & $7.4 \times 10^{-4}$
\end{tabular}

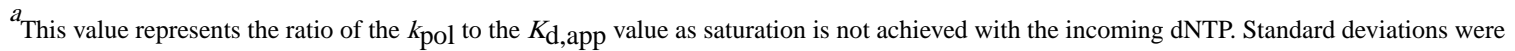

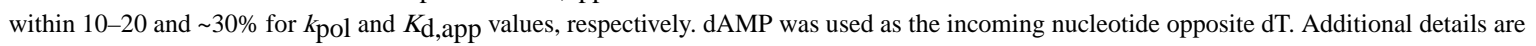
provided in Materials and Methods. 
Table 5

Summary of $k_{\text {exo }}$ Values for Wild-Type RB69pol Using Different Metal Ions with a Complementary P/T $\left(\mathrm{DNA}_{13 \mathrm{~A}}\right)^{a}$

\begin{tabular}{lcc}
\hline metal ion & $\boldsymbol{k}_{\text {exo }}\left(\mathbf{s}^{-\mathbf{1}}\right)$ & $\boldsymbol{x}$-fold decrease $\boldsymbol{b}$ \\
\hline $\mathrm{Mg}^{2+}$ & 6.6 & 1.0 \\
$\mathrm{Co}^{2+}$ & 1.0 & 6.6 \\
$\mathrm{Mn}^{2+}$ & 3.0 & 2.0 \\
$\mathrm{Ni}^{2+}$ & 0.2 & 33 \\
${ }^{a}$ Standard deviations were within $10-20 \%$ for $k_{\text {exo. }}$ \\
$b$ Defined as $\left(k_{\text {exo }}\right) \mathrm{Mg}^{2+} /\left(k_{\text {exo }}\right)$ other metal ion.
\end{tabular}




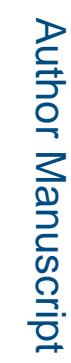

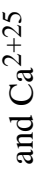

莫

$\stackrel{+}{\stackrel{*}{\Sigma}}$

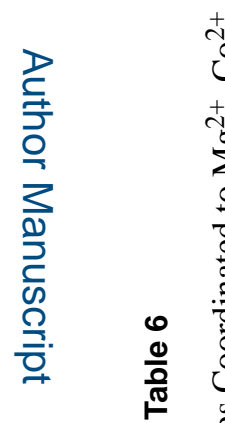

$\stackrel{+}{0}$

$\stackrel{+}{\overbrace{0}}$

$\sum_{0}^{\infty}$

过

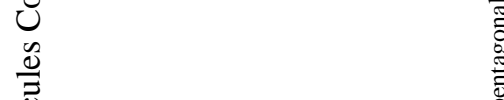

$\frac{0}{\frac{0}{7}}$

롤

㐫

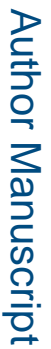

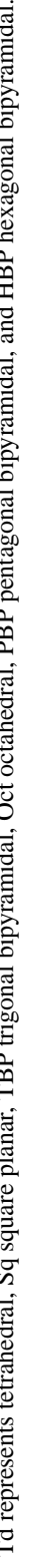

Biochemistry. Author manuscript; available in PMC 2018 June 06. 